\title{
Archaeological Monitoring for the Tri-Party Improvements Project, San Antonio, Bexar County, Texas
}

I. Waynne Cox

Center for Archaeological Research

Follow this and additional works at: https://scholarworks.sfasu.edu/ita

Part of the American Material Culture Commons, Archaeological Anthropology Commons, Environmental Studies Commons, Other American Studies Commons, Other Arts and Humanities Commons, Other History of Art, Architecture, and Archaeology Commons, and the United States History Commons

Tell us how this article helped you.

This Article is brought to you for free and open access by the Center for Regional Heritage Research at SFA ScholarWorks. It has been accepted for inclusion in Index of Texas Archaeology: Open Access Gray Literature from the Lone Star State by an authorized editor of SFA ScholarWorks. For more information, please contact cdsscholarworks@sfasu.edu. 


\section{Archaeological Monitoring for the Tri-Party Improvements Project, San Antonio, Bexar County, Texas}

\section{Creative Commons License}

\section{(c) (1) (8)}

This work is licensed under a Creative Commons Attribution-NonCommercial 4.0 International License 


\section{ARCHAEOLOGICAL MONITORING FOR THE \\ TRI-PARTY IMPROVEMENTS PROJECT, \\ SAN ANTONIO, BEXAR COUNTY, TEXAS}

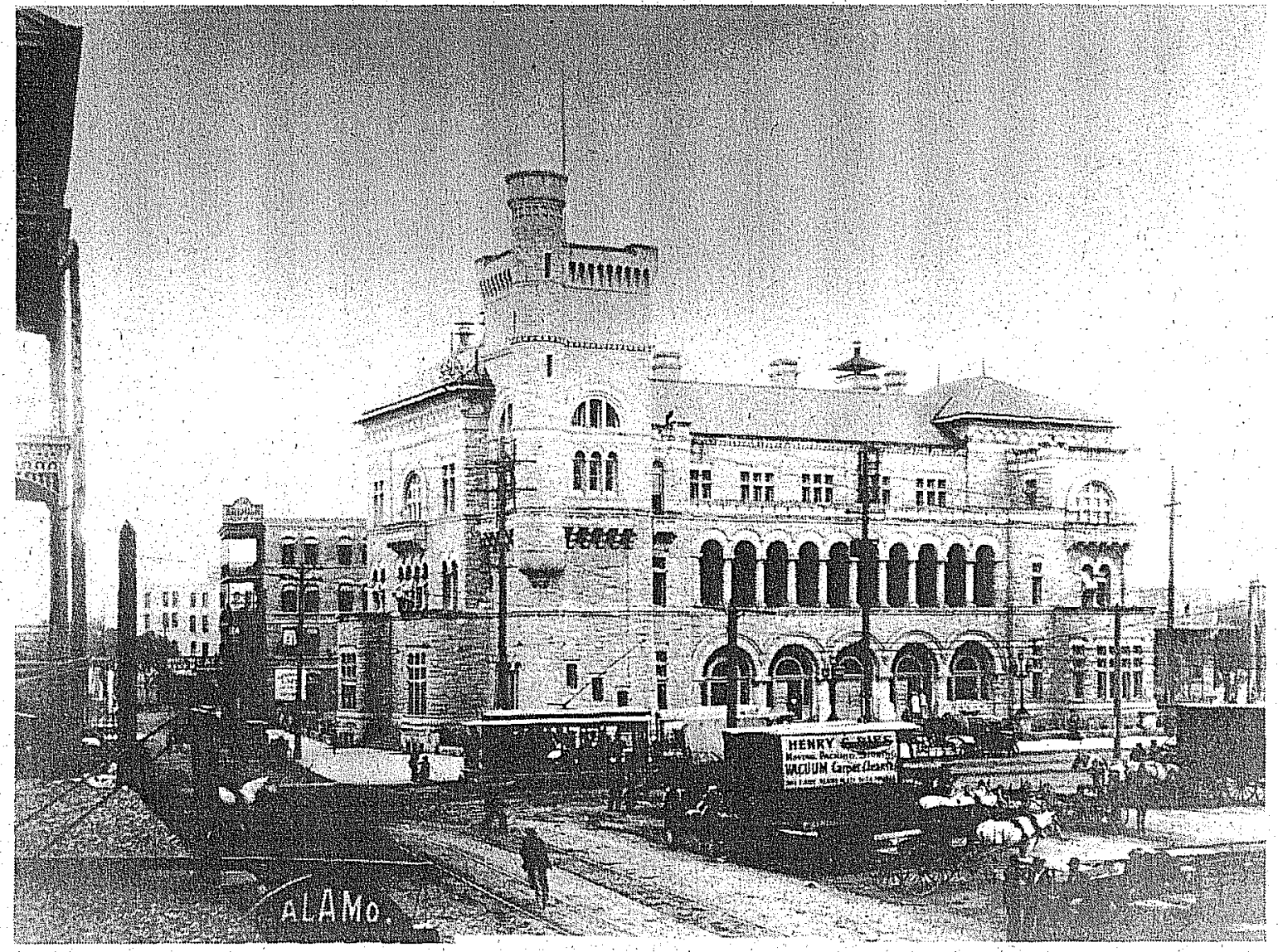

I. Waynne Cox

Center for Archaeological Research

The University of Texas at San Antonio

Archaeological Survey Report, No. 204 

Federal Building on Alamo Plaza, 1900-1901. Courtesy of the Daughters of the Republic Research Library, The Alamo. 



\title{
ARCHAEOLOGICAL MONITORING FOR THE TRI-PARTY IMPROVEMENTS PROJECT, SAN ANTONIO, BEXAR COUNTY, TEXAS
}

\author{
I. Waynne Cox
}

Texas Antiquities Permit No. 657

Center for Archaeological Research The University of Texas at San Antonio@ Archaeological Survey Report, No. 204 
The following information is provided in accordance with the General Rules of Practice and Procedure, Chapter 41.11 (Investigative Reports), Texas Antiquities Committee:

1. Type of investigation: archival research and archaeological monitoring;

2. Project name: San Antonio Downtown Tri-Party Transportation Improvements project;

3. County: Bexar;

4. Principal investigator: Jack D. Eaton; coprincipal investigator: Anne A. Fox;

5. Name and location of sponsoring agency: San Antonio Metropolitan Transit Authority;

6. Texas Antiquities Committee Permit No. 657;

7. Published by the Center for Archaeological Research, The University of Texas at San Antonio, San Antonio, Texas 78249-0658, 1992.

A list of publications offered by the Center for Archaeological Research can be obtained by sending $\$ 1.00$ to the Center for Archaeological Research, The University of Texas at San Antonio, San Antonio, Texas $78249-0658$. 


\begin{abstract}
In 1987, the Center for Archaeological Research entered into a contract with the San Antonio Metropolitan Transit Authority to provide consultant services for the downtown San Antonio Tri-Party Improvements project. Preliminary research was provided prior to initiation of construction, and monitoring was conducted during the three years of modifications to the downtown area. The archaeological resources exposed during the project were researched and documented, and recommendations were made throughout the construction period.
\end{abstract}




\section{TABLE OF CONTENTS}

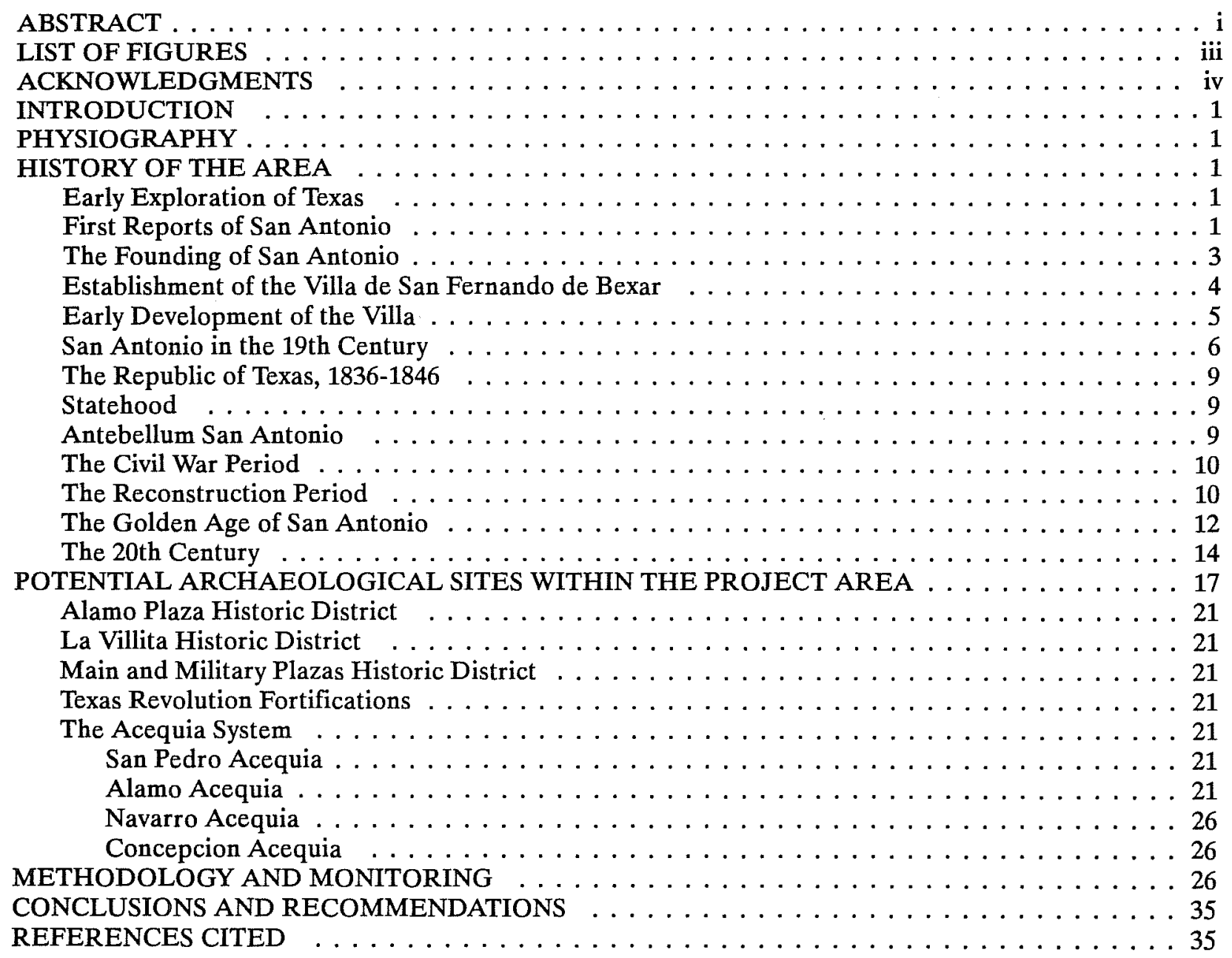




\section{LIST OF FIGURES}

1. Tri-Party Improvements Area . . . . . . . . . . . . . . . . . . . 2

2. Villa de San Fernando de Bejár, ca. $1767 \ldots \ldots \ldots \ldots \ldots \ldots \ldots \ldots \ldots$

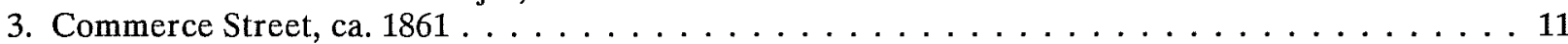

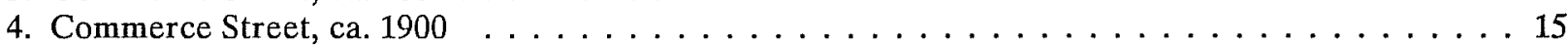

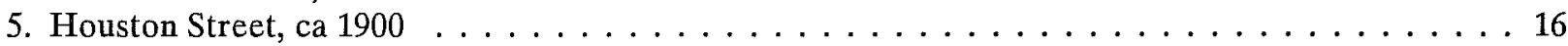

6. The Widening of Commerce Street in $1912 \ldots \ldots \ldots \ldots \ldots \ldots$. . . . . . . . . . 18

7. Lt. Foulis at Fort Sam Houston, $1910 \ldots \ldots \ldots \ldots \ldots \ldots \ldots$

8. Historic Districts within the Tri-Party Improvements Area $\ldots \ldots \ldots \ldots \ldots$

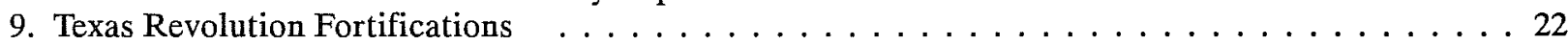

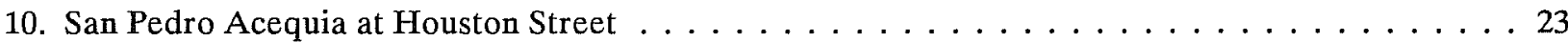

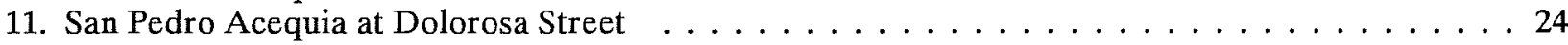

12. Alamo Acequia at Houston Street . . . . . . . . . . . . . . . . . . . 25

13. Alamo Acequia at Crockett Street and Navarro Acequia . . . . . . . . . . . . . . . . 27

14. Alamo Acequia at the Alamo . . . . . . . . . . . . . . . . . . . . . 28

15. Concepcion Acequia . . . . . . . . . . . . . . . . . . . . . . . . . . 29

16. Sanborn 1896 Insurance Maps . . . . . . . . . . . . . . . . . . . . . . . . 30

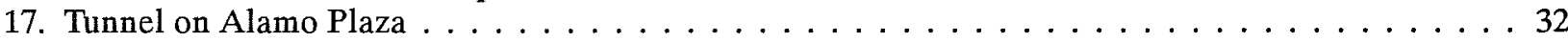

18. Federal Building on Alamo Plaza, $1900-1901 \ldots \ldots \ldots \ldots \ldots \ldots \ldots$

19. Sanborn 1896 Insurance Maps . . . . . . . . . . . . . . . . . . . . . . . . . 34

20. San Pedro Acequia on Main Plaza, ca. $1880 \ldots \ldots \ldots \ldots \ldots \ldots$ 


\section{ACKNOWLEDGEMENTS}

We would like to take this opportunity to express our gratitude to a few of themany people and agencies that made this project possible. The staff of Gilbane, Garcia \& Wright was extremely aware of the necessity of full cooperation and coordination throughtout the project. Likewise, the prime contractor, Clearwater Construction, was diligent in alerting the CAR of potential problems and tolerant of our requirements when they appreared.

As always the county archivist, John Ogden Leal, Homer San Miguel, city right-of-way office, and the staff of the library of the Daughters of the Republic of Texas and the San Antonio Public Library rendered invaluable assistance in making their research materials available. A special thanks is due to Martha Utterback, library of the Daughters of the Republic of Texas, and Diane Bruce, Institute of Texan Cultures, for their diligent work in obtaining photographs for this report. Pat Osborne, city historic preservation officer, again contributed valuable pointers and assisted the archaelogist in insuring that valuable information was not overlooked. 


\section{INTRODUCTION}

In the latter part of 1987, the Center for Archaeological Research, The University of Texas at San Antonio (CAR-UTSA) entered into a contract with the San Antonio Metropolitan Transit Authority (VIA) to provide consultation services for the downtown Tri-Party Improvements project. The Tri-Party project was a joint venture of the City of San Antonio, VIA, and the Downtown Owner's Association to beautify and revitalize the downtown area. Some 70 blocks of 13 downtown streets were targeted to be remodeled, redesigned, and revamped, major bus routes streamlined; benches, water fountains, and trees installed; and new brick pavers placed throughout the area (Fig. 1). Since much of this work would entail major excavation of the oldest portion of the city, it was recognized that it would be critical to identify in advance particularly sensitive areas and closely monitor all operations to insure that irreplaceable historic sites would not be destroyed. Monitoring began with the initiation of the construction phase June 27, 1988, and continued until the completion of the project in early 1991.

Texas Antiquities Committee Permit No. 657 was issued for the project. Jack D. Eaton, acting director of the CAR, served as principal investigator, and Anne A. Fox served as co-principal investigator. All field notes, photographs, and drawings pertaining to this project are on file at the CAR-UTSA.

\section{PHYSIOGRAPHY}

San Antonio is situated in central Bexar County, located on the northern edge of the Nueces Plains and intruded on the northeast by the Blackland Prairies. The topography of the county is dominated by the Balcones Escarpment, a limestone uplift. The land to the north is rugged, and slopes are steep, while to the south, the area is gently rolling alluvium and clay (Southwest Research Institute 1979:IV-A; Environmental Protection Agency 1978:xiii). The Balcones Escarpment spans most of Central Texas, sweeping in an arc from Waco to Austin to Del Rio. The Edwards limestone fault displaces the Austin chalk and Taylor marl to create an extensive underground reservoir, the Edwards aquifer. The water, under artesian pressure, is forced upward along the fault planes creating, by far, the most prolific springs in Texas (Brune 1981:14-15). These springs, bursting forth to create the limpid waters of the San Antonio Basin, have attracted man since his earliest occupation of Central Texas and served as the principal attraction for the founding of San Antonio.

\section{HISTORY OF THE AREA}

\section{EARLY EXPLORATION OF TEXAS}

Although the area we now know as Texas was considered a portion of New Spain since the conquest of Mexico in 1540, Spanish interest in the area was extremely limited. The explorations into the area by the ill-fated Cabeza de Vaca in 1520, of Coronado in 1540, Moscoso in 1541, and Oñate in 1598 , did little to excite interest in the area when they failed to find the rumored riches of gold or silver (Steen 1948:1-9). Their observations gave no reason for immediate settlement, but Spain maintained its claim to all the land north to the Red River. The claim was severely challenged when word reached the viceroy that the French planned to settle within the area. The appearance, in 1684, of René Robert Cavalier, Sieur de La Salle, at Matagorda Bay created great distress and prompted three attempts to locate the intruders. The last, led by Don Alonso de León, reached the ruins of La Salle's Fort St. Louis in April 1689 (Fehrenbach 1968:40). Spain felt compelled to create a buffer area to prevent further intrusion into the territory. In 1690, De León, prompted by the zeal of Fray Francisco Hidalgo, returned to Texas to establish Mission San Francisco de los Tejas near the Trinity River. The mission venture failed in 1693, and the Spanish again withdrew from the inhospitable province (Webb 1952 Vol. I:483, Vol. II:552).

\section{FIRST REPORTS OF SAN ANTONIO}

The first official description of the San Antonio region was recorded during the third official entrada into Texas in 1691 by the expedition of Don Domingo de Terán on the way to the newly formed East Texas missions (Hatcher 1932:14):

On the 13th [June 1691] our royal standard and camp moved forward in the aforesaid easterly direction. We marched five leagues over a fine country with broad plains - the most beautiful in New Spain. We camped on the banks of an arroyo adorned by a great number of trees, cedars, 


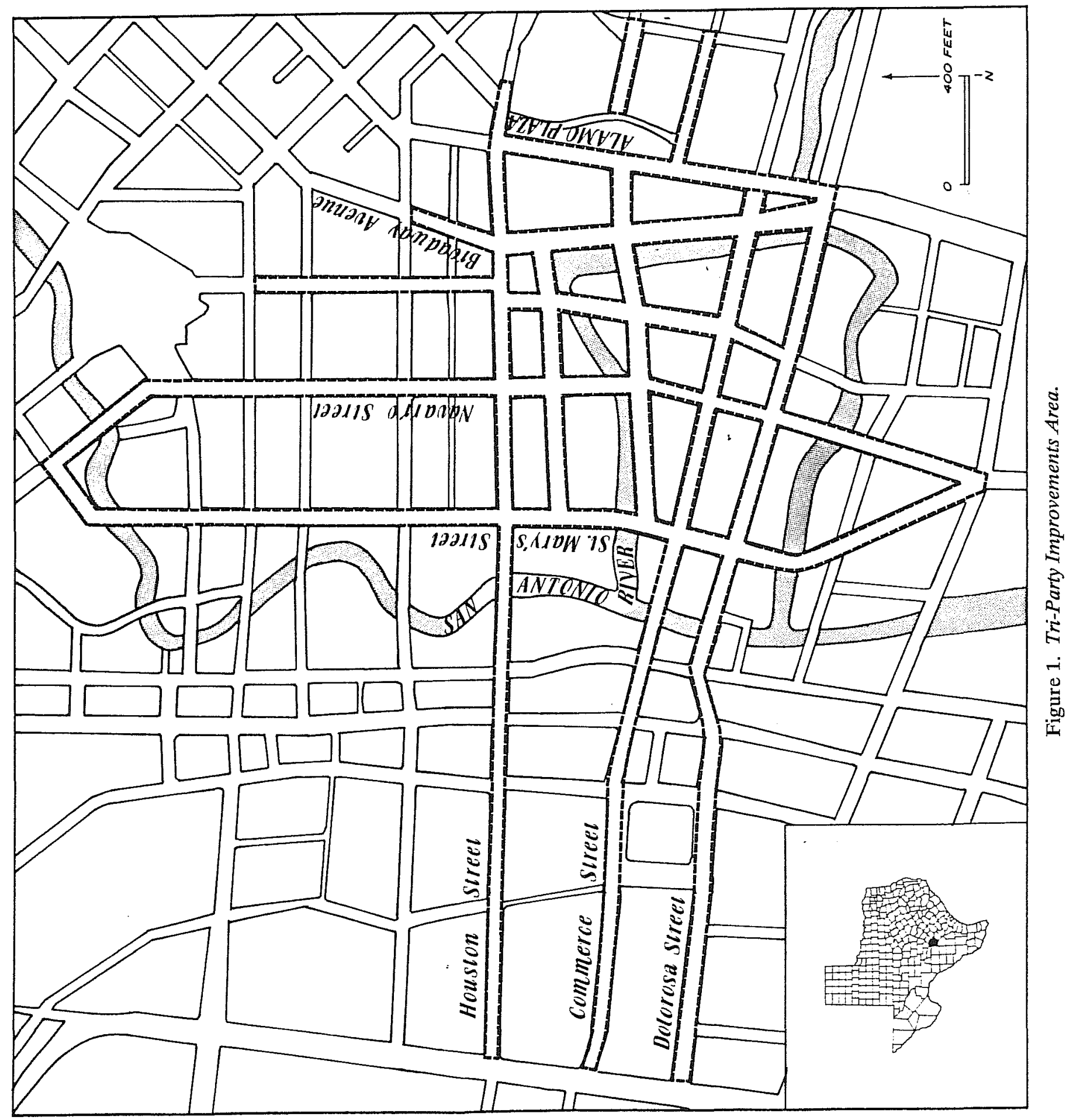


willows, cypress, osiers, oaks, and many other kinds. This I called San Antonio de Padua, because we reached it on his day.

It seems from the description of their route to the river that their crossing must have been well to the south of the present site of Mission Concepción, for there is no mention of either San Pedro Creek or of the springs.

Although the East Texas missions were abandoned in 1693, the founding of the colony of Louisiana in 1699 again stirred the concern of Spain. In April 1709, Fray Isidro Felix de Espinosa and Fray Antonio de San Buenaventura Olivares, accompanied by Captain Pedro de Aguirre, departed Mission San Juan Bautista on the Rio Grande with the intent of reestablishing contact with the Tejas Indians. On April 13, they arrived at the present site of San Antonio. Fray Espinosa commented (Tous 1930a:5):

We crossed a large plain ... and after going through a mesquite flat and some holm-oak groves we came to an irrigation ditch, bordered by many trees and with water enough to supply a town. It was full of taps or sluices of water, the earth being terraced. We named it Agua de San Pedro and at a short distance we came to a luxuriant growth of trees, high walnuts, poplars, elms, and mulberries watered by a copious spring which rises near a populous rancheria of Indians ... numbering in all about 500 persons, young and old. The river, which is formed by this spring, could supply not only a village, but a city, which could easily be founded here because of the good ground and the many conveniences, and because of the shallowness of said river.

Although no tangible effects resulted from this venture into Texas, it spurred the zeal of Fray Olivares and Fray Hidalgo to reestablish the missionary effort of 1690 . Fray Hidalgo, sensing apathy toward the idea in the Spanish government, conveyed a letter suggesting trade negotiations to the governor of the Louisiana colony, Antoine de la Mothé Cadillac. The governor dispatched the trader Louis Juchereau de St. Denis to Mission San Juan Bautista to contact the astonished Spanish official, Captain Diego Ramón.
St. Denis was so persuasive that in 1716 , now married to Captain Ramón's granddaughter, he was allowed to serve as guide for a new venture into Texas. The expedition, commanded by Alferez Domingo Ramón, brother of Captain Diego Ramón, departed in April for the land of the Tejas (John 1975:207). The large entourage, including about 40 persons who planned to make their home in the new region, arrived at the San Antonio River on May 14. The enthusiastic Fray Espinosa recounted its wonders anew (Tous 1930b:9-10):

... we entered the plain at the San Antonio River ... to it succeeds the water of the San Pedro, sufficient for a mission. Along the bank of the water, which has a thicket of all kinds of wood, and by an open path we arrived at the River San Antonio. This river is very desirable and favorable for its pleasantness, location, abundance of water, and multitude of fish. It is surrounded by very tall nopals, poplars, elms, grapevines, black mulberry trees, laurels, strawberry vines and genuine fan-palms. There is a great deal of flax and wild hemp, an abundance of maiden-hair fern and many medicinal herbs. Merely in that part of the density of its grove which we penetrated seven streams of water meet. These, together with others concealed by the brushwood, form at a little distance its copious waters which are clear, crystal and sweet.... This place mellowed the dismal remembrance of the preceding one. Its luxuriance is enticing for the founding of missions and villages, for both its plain and its waters encourage settlement.

The expedition founded four missions in East Texas, San Francisco de los Tejas, Nuestra Señora de los Dolores de los Tejas, Nuestra Señora de la Purísima Concepción de Acuña, and San José de los Nazones. Within the year, two more missions were established for the Adaes and the Ais (John 1975:208).

\section{THE FOUNDING OF SAN ANTONIO}

One of the few concepts agreed upon by both the viceroy and the clergy was that the failure of the 
earlier mission effort was, in part, due to the difficulty of resupply from the nearest, but remote, Spanish settlement on the Rio Grande. Therefore a way station was necessary for the welfare of the East Texas missions. Governor Don Martín de Alarcón, accompanied by seven families of settlers and Father Olivares, departed Mission San Juan Bautista April 9, 1718, but because of their disagreements they traveled separately. They arrived at the San Antonio River April 25. After exploring the vicinity, Father Olivares independently founded a small mission, San Antonio de Valero, "... near the first spring [San Pedro], half a league [1.29 miles] from a high ground and adjoining a small thicket of live oaks, where he is building a hut" (Hoffman 1938:318). The Celiz diary places the location "about three-fourths of a league [1.94 miles] down the creek" (Hoffman 1935:49). Very shortly afterward the mission was moved to the east bank of the river south of its present location, where it remained until destroyed by a hurricane in 1724 , when it was moved to its present location (Chabot 1937:140).

On May 5, 1718, the governor, "fixing the royal standard with the requisite solemnity," established the Villa de Bejár, near San Pedro Springs, named in honor of the brother of the viceroy (Hoffman 1935:49). Leaving the settlers and a contingency of troops, he proceeded toward the East Texas settlements. Upon his return, in January of the following year, he found that "nothing unforeseen what so ever had happened," and he ordered supplies, livestock, and munitions for the villa. He also gave orders to "begin with all assiduity the construction of canals for both the villa and the mission of San Antonio de Balero (sic)," the beginning of the San Antonio acequia system (Hoffman 1935:22).

However, conditions in East Texas rapidly grew worse, the crops failed, disease took its toll, and some of the soldiers deserted (Steen 1948:22). After an attack by the French on Mission San Miguel de los Adaes in the summer of 1719, the Spanish withdrew all activity to Bejár. The missionaries built temporary huts at Mission San Antonio de Valero to await the return of the governor to escort them back to their stations (John 1975:224). One of these refugees, Fray Antonio Margil de Jesus, encountered three groups of Indians who desired mission life but could not tolerate the Indians of the established mission. To accommodate them he founded a second mission farther down the river, named Mission San José y San Miguel de Aguayo in honor of the Marquis de Aguayo, a personal acquaintance (Habig 1968a:26).
In April 1721, Aguayo reached the villa with a force of about 500 men and 4000 horses and other livestock. Accompanied by the dispossessed friars, the expedition proceeded onward to East Texas, where he reestablished six missions and the Presidio Nuestra Señora de los Tejas, as well as founding the Presidio Nuestra Señora del Pilar de los Adaes (Webb 1952 Vol. I:17).

As Aguayo reached the Trinity River upon his return, he was informed that the presidio at Bejár had burned. Sixteen huts and the granary, and its supply of 700 bushels of corn, had been destroyed. Upon his arrival in San Antonio, January 23, 1722, he ordered the reconstruction of the presidio with "accident-proof" adobe (Turanza 1961:75-76) and the relocation to a site between the river and San Pedro Creek (present Military Plaza), opposite the new location of San Antonio de Valero. He designed the fortress "as a square with four bulwarks and curtain walls 65 varas [ 180.5 feet] in length." $\mathrm{He}$ also ordered the construction of an acequia from San Pedro Springs to serve the presidio (Santos 1981:75-76). The location of San Antonio was thus fixed into its present location and configuration for future growth.

In 1727, Brigadier Pedro de Rivera y Villalón made an inspection tour of the frontier presidios and recommended removal of the distant settlements toward the interior. As a result three of the East Texas missions were moved to the San Antonio River in 1731. These missions were renamed Nuestra Señora de la Concepción, San Juan Capistraño, and San Francisco de la Espada (John 1975:262).

\section{ESTABLISHMENT OF THE VILLA DE SAN FERNANDO DE BEXAR}

Rivera also recommended to the King that the territory be settled with families from the Canary Islands, believing that "one permanent Spanish family would do more to hold the country than a hundred soldiers" (Chabot 1937:141). On March 9, 1731, fifty-six persons from the Canary Islands arrived at the presidio to form the nucleus of the villa of San Fernando de Bejár, the first civil government of Texas (Webb 1952 Vol. I:288). Although generally considered to be the "first families" of San Antonio, they were by no means the only bona fide settlers of the area. Other settlers had been established there since 1716 , and numerous documents make references to the vecinos antiquas (old citizens) of the villa (Aviles 1732; Cox 1902:147). 
Upon the orders of the Marques de Casafuerte, Antonio de Aviles, the newcomers were greeted and housed by the captain of the presidio, Don Juan Antonio Pérez de Almazán. The original orders directed that the villa be established a "gun shot's distance ... to the west of the Presidio," and specified the exact limits of the Royal grant (Almazán 1731). However, Almazán delayed the laying out of the villa until after the planting season, selecting the "land subject to irrigation" between the river and the creek to the north and south of the presidio as temporary fields.

The following July 2 , he called the families together, instructing each to bring two cart loads of large stones and 10 stakes, and to begin the survey of the town. Due to the lack of water to the west of the presidio, a site "a gun shot's distance to the east" was selected for the settlement (Almazán 1731). Using a cord of 50 common varas in length, he began to establish the villa by selecting the location of the church. The proximity of the presidio to the west required that he reorient the church to face the east. From the middle of the point designated for the church door, he laid out a plaza 200 varas $(555.5$ feet) in length and 133-1/3 varas (370.37 feet) in width, including in the last measurement the width of the streets, each 13-1/2 varas (37.03 feet). The block for the Casas Reales was established across the plaza facing the church.

During the next two days, he laid out a cruciform town site in the cardinal directions from the church. On July 5, he measured 1093 varas (3036.11 feet) in all four directions to establish a square about the cruciform of 2186 varas (6072.22 feet) oriented $45^{\circ}$ toward the northeast and southwest. This was designated as pasture and grazing lands for the town. The original decree dictated a second square around the first an additional 2180 varas (6055.5 feet) farther from each extreme. The constraints of the river and previously assigned mission lands required Almazán to alter the dimensions in order to obtain the allotted measure of land remaining for the ejidos or common lands (Almazán 1731:1-24).

\section{EARLY DEVELOPMENT OF THE VILLA}

The young villa and presidio were visited, in 1767, by Pierre Marie Francois Pagés, a captain in the French navy. His description of San Antonio gives a view of the presidio (Steele 1985:18):

The settlement of San Antonio is on flat land. One of its sides occupies the opening of a bend of a small river....
It is encircled by stone walls of the houses which surround it, and the entrances are protected by stone palisades. As the settlement is quite large and some houses are ruined, it is not completely enwalled, and it takes quite a lot of people to guard it. Outside the settlement are scattered huts which cover and facilitate the enemy's approach. The bend of the river is likewise full of huts, lived in by colonists who are natives of the Canary Islands. . . . All around it are corn fields which are very fertile and well irrigated by the water of the river, which has been diverted into a number of canals.... The number of houses is perhaps two hundred, of which two thirds are constructed of stone. They are covered by roofs of packed earth which are adequate due to the little rain and the clear skies of this country.

Although envisioned to develop into the orderly model prescribed by the plan of the Law of the Indies, the small frontier settlement grew slowly and of its own accord. Fray Juan Agustín de Morfi, chaplain to the inspection tour of Don Theodoro de Croix, presented this unflattering picture of San Antonio as he perceived it in 1778 (Chabot 1932:57-58):

I am not afraid to affirm then, that in all the expanse of New Spain, there is not a more beautiful, nor more opportune place for the founding and maintaining of a great city than that at the site of the Villa of San Fernando and Presidio of San Antonio de Bejár ... comprising one single settlement; but so mean (mezquina) that it hardly deserves the name of village (aldea). All of its buildings do not number over 59 little houses, of stone and mud, and 79 frame huts (choxas de madera). The greater part of them have only one small room. All are low, without floors, and comforts; and even without appearance.

The streets are without regularity, and so poorly cared for that as soon as it rains it is necessary to mount horseback to leave the houses. 
The church which was built at the expense of the Royal Hacienda, is large enough for such a place. It is already threatening to fall in ruins, though it is quite modern; and it is so much without ornamentation that the most wretched pueblo would have a much more decent one.

The cost to His Majesty for the founding of this Villa and Presidio exceed 80,000 pesos, and if all the buildings were sold today, no one who had seen them in person, would give even 800 pesos for them.

... they do not appreciate the reason that His Majesty at great cost had them brought from the Canary Islands. They wish to act as gentlemen (cavalleros) and scorn the cultivation of the land whose fertility reprimands the laziness of these colonists, who notwithstanding all their false pride, are not ashamed to depend for their subsistence on the indians of the nearby mission, from whom they beg their food.

The villa, as seen by these visitors, is illustrated in Figure 2, which is based on a drawing by Urrutia (1767).

In 1779, Governor Don Domingo Cabello received orders to close the mission and divide the lands among the Indians, this was, however, not carried out at this time. On January 9, 1793, Governor Manuel Munoz ordered the suppression and secularization of the mission.

\section{SAN ANTONIO IN THE 19TH CENTURY}

In 1801, the presidio garrison was augmented by the arrival of the Flying (Mobile Cavalry) Company of San José y Santiago del Alamo de Parras, who took up quarters in the now abandoned mission. From this occupation, the presidio received its more famous name, "the Alamo" (Ramsdell 1976:17).

In 1807, Zebulon Montgomery Pike, on his expedition to explore the headwaters of the Arkansas and Red Rivers, entered San Antonio and was received by the Spanish officials. He describes the town thus (Coues 1965:783-784):
... it contains perhaps 2,000 souls, most of whom reside in miserable mud-wall houses, covered with thatched grass roofs. The town is laid out on a very grand plan. To the east of it, on the other side of the river, is the station of the troops.

In January 1811, the revolution started in Mexico by Father Miguel Hidalgo spread to Texas, specifically San Antonio. Juan Bautista Casas, with the presidial troops of Bejár, placed himself as head of government and declared for Hidalgo. His despotic and disorderly administration was overthrown March 2, when he surrendered to the opposing forces. He was sent to Mexico, tried, beheaded, and the head shipped to San Antonio to be displayed as a warning to other rebels (Webb 1952 Vol. I:305; Faulk 1964:134).

In March 1813, the city was captured by the forces of the Republican Army of the North, and the following August 18, General Joaquin de Arredondo, with some 4000 men, met and defeated the insurgents south of the Medina River in what has been termed the "bloodiest battle ever fought in Texas" (Schwartz 1985:xi). Arredondo's retribution was swift and bloody. Hundreds of rebels were imprisoned in the guardhouse and the home of Francisco Arocha, where eight suffocated during the night (Schwartz 1985:108). In all, 327 rebels were recorded as executed in Bejár alone. The wives and daughters were imprisoned for 54 days in the "Quinta" (now Dwyer Street) where they were forced to grind corn for tortillas from two in the morning until ten o'clock at night to feed the conquerors (Garrett 1968:225). The after-effects left the town in a shambles, the property of the citizens confiscated, and the majority of the men either dead or having fled the country.

As the city was recovering from the effects of this slaughter, it was beset by a natural disaster. Governor Antonio Martínez wrote to Viceroy Juan Ruiz de Apodaca to inform him of the state of affairs (Quirarte 1983:34):

... about five o'clock on the morning of the 5th of this month [July 1819], and suddenly without the least chance of averting disaster, the torrent of water left its channel and spread over the town with a force beyond imagination; houses were washed from their foundations with the families inside; they were seen to revolve in whirlpools formed by the rushing waters; then lashed by the 


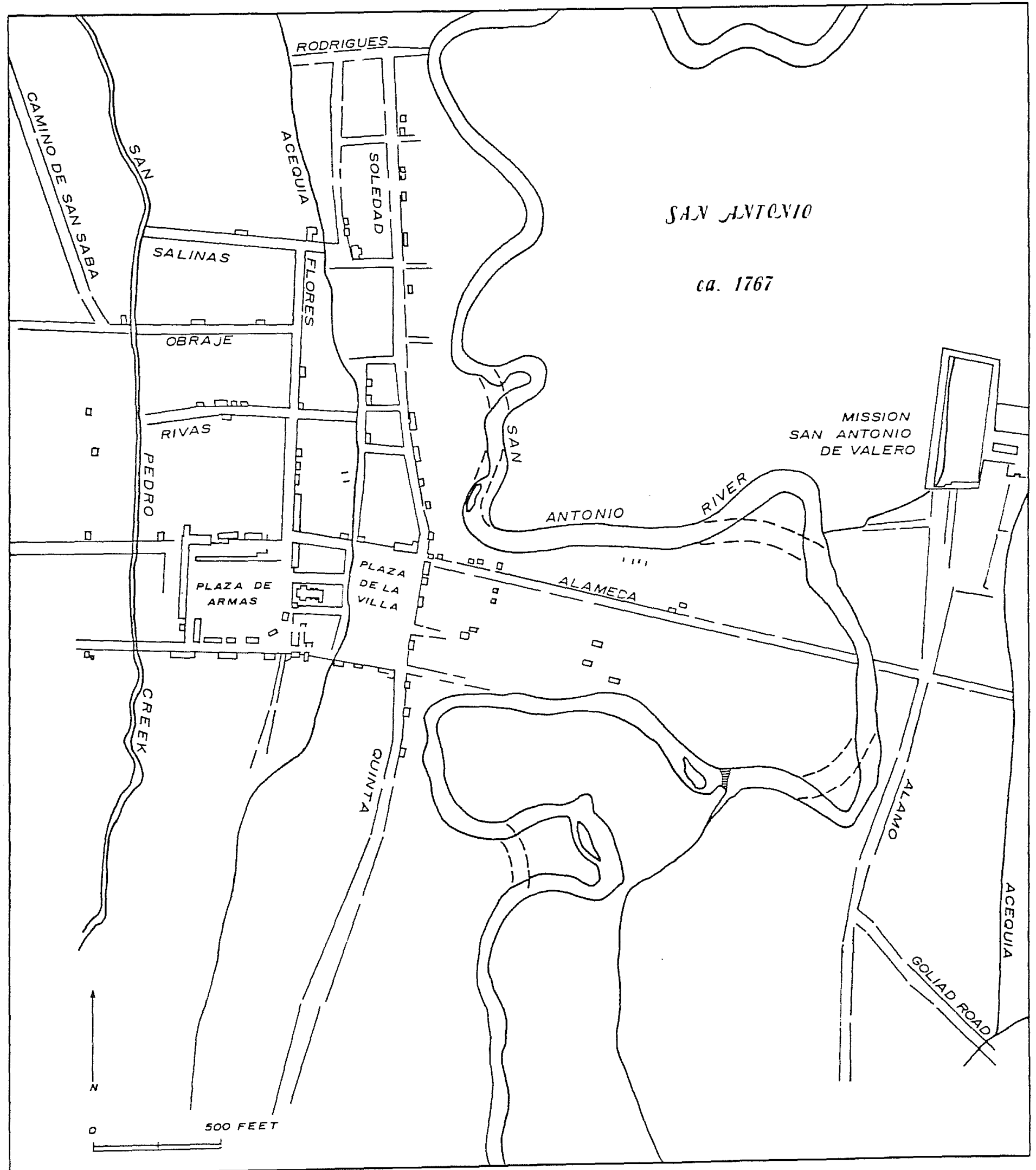

Figure 2. Villa de San Fernando de Bejár, ca. 1767. 
houses began to disappear, leaving only fragments afloat to indicate the disaster that overtook them. In the said semicircle, formed by the bend of the river, there was hardly a house standing on the east side; all being made of wood they could not resist the force of the waters, and in the center of the town, although you could see some of the houses of stone, they were also ruined because the main walls in the interior were demolished, and the water overcame all resistance and split the rest into pieces from top to bottom in several places, and then all of them fell quickly.

The result of these calamities was a sharp reduction in the population of San Antonio. This population drop was so severe that a Spanish inspector, Juan Antonio Padilla, recommended the restoration of all confiscated properties to "the original and legitimate owners" to encourage their return (Hatcher 1919:64). In December 1820, Moses Austin appeared in San Antonio with a partial solution to the lack of settlers in Texas, a request for authority to bring a colony of Anglo-Americans to Texas. His petition was granted January 17, 1821, allowing Austin to settle 300 families on 200,000 acres. After his death, in June of that year, his son, Stephen Fuller, carried the project into reality. Other impresarios soon followed, producing a steady flow of immigrants (Webb 1952 Vol. I:80-84). This influx of settlers was primarily into East Texas. By mid-1826 the population of San Antonio was only 1625. Indian depredations and the loss of stature with the shift of the capital to Saltillo with Mexican independence in 1821 added to San Antonio's growth problems (Mayer 1976:64). While this influx of population achieved the colonization of the province, long recommended by such leaders as Ramón Musquiz, it created a colony largely made up of Anglos with little loyalty or dedication to the Mexican state. This was recognized as early as 1825 by José Maria Sanchez when he reported (Castañeda 1926:261):

The vigilance of the highest authorities has been dulled while our enemies from the north do not lose a single opportunity of advancing though it be only a step toward their treacherous design which is well known.
This eastern concentration of Anglo settlers is evident in the report of Juan Almonte, in 1835, which states that "the population of the department of Bexar, with the exception of San Patricio [the Irish colony of John McMullen], is made up in its entirety of Mexicans" (Castañeda 1925:186). The growing unrest in the state was brought to a head when the army was moved to San Antonio by General Martín Perfecto de Cós in order to enforce submission to Mexican authority. In September 1835, Austin returned from two years of Mexican imprisonment convinced that Texas must become a separate state, thus placing the colonies in direct opposition with the policies of President General Antonio Lopéz de Santa Anna. Knowing the result of this action, Austin mustered the forces of the colonies in anticipation of armed conflict with the Mexican army.

In late October 1835, the Texan army approached San Antonio and encamped near Cibolo Creek. General Cós, with two divisions of men, began to fortify the Alamo and his headquarters on Military Plaza (Green 1921:133-134). His fortifications on the plazas consisted of the following (Johnson and Barker 1914 Vol. I:353-354):

... a breastwork, and one gun, was thrown up at the northeast angle of Constitutional [Main] Plaza, also a breast and gun at the entrance of the street from the Alamo, in Constitution Plaza. At the southwest angle of Military Plaza was another breastwork, and at the northwest angle was erected a breastwork with one gun and a furnace for heating shot. About midway of this plaza, north boundary, was a redoubt with three guns.

The Texan force of some 300 men, under the leadership of Benjamin R. Milam and Frank W. Johnson, attacked the city December 5, concentrating their assault upon the plazas. After fierce combat, General Cós surrendered the city December 9 (Webb 1952 Vol. I:154).

On February 23, 1836, General Santa Anna and the first of his troops arrived at San Antonio to avenge the 1835 defeat. They laid siege to the Texan army, now under the joint command of William B. Travis and James Bowie, who had taken refuge within the walls of the Alamo. Several new fortifications were constructed in the city, and some of the older fortifications were rearmed. The battle ended March 6 with the fall of the Alamo and the 
fortifications were constructed in the city, and some of the older fortifications were rearmed. The battle ended March 6 with the fall of the Alamo and the deaths of its defenders (Webb 1952 Vol. I:22-23). General Santa Anna's defeat in the 18- minute rout at San Jacinto on April 21, 1836, signaled the birth of the Republic of Texas (Webb 1952 Vol. II:554).

\section{THE REPUBLIC OF TEXAS, 1836-1846}

The emergence of Texas as a Republic did not immediately correct the internal problems or its restricted growth. As a Republic, its autonomy and territorial claims were challenged, erupting into open warfare with Mexico throughout the decade of existence of the financially troubled Republic.

In August 1838, Vicente Cordova, a long-time opponent of the Anglo-American settlers, rebelled against the fledgling Republic, prompting President Thomas J. Rusk to call out the militia to suppress the rebellion (Webb 1952 Vol. II:412). In March 1842, Rafael Vásquez, commander of the Mexican Centralist, occupied San Antonio with 500 to 700 men (Webb 1952 Vol. II:834). In September of the same year, General Adrian Woll again captured San Antonio and carried off many of its leading citizens (Webb 1952 Vol. II:928).

\section{STATEHOOD}

The annexation of the Republic by the United States, in February 1846, solved in part its financial problems, but not its border problems. Mexico continued to contest the disputed territory, resulting in the movement of American troops, under General Zachary Taylor, across the Nueces River, provoking the war with Mexico (Webb 1952 Vol. II:276).

Yet, despite these problems, the time between annexation and secession marked the period of the most rapid growth in the state's history. Population increased by more than fourfold and assessed property by twice that figure. Immigration was from the Old South, composed of $90 \%$ native born Americans (Fehrenbach 1968:279).

San Antonio also experienced this growth, but with an entirely different character. The population of San Antonio in 1830 numbered only 1621 (White 1983:77), and by 1840, had increased to only approximately 2000 (Nance 1963:450). In 1850 , the first United States census indicated a population of 3488 (USDI-OC 1850), but by 1860 , the population had surged to 8235 , an increase of
136\% (USDI-OC 1860; Bybee 1980:33). However, San Antonio's growth was primarily prompted by immigration from Europe. By 1850, Europeans, mostly German, outnumbered both Mexican and Anglo (Fehrenbach 1968:285).

Unprecedented growth created a phenomenon new to this raw frontier, land speculation. Poor in specie, but rich in land, as guaranteed by its unique agreement of its right upon annexation to retain all public lands, the state was generous with its primary asset. Land grants and headrights as a reward for valor, longevity, residency, or immigration were freely granted. Vast tracts of land, unseen and unsurveyed, changed ownership throughout the state, but the center of this exchange was the edge of the frontier, Bexar County (Pitts 1966:11). Samuel A. Maverick (1838) wrote his wife, Mary:

The land business is carried on by the most artful fellows on earth and they stop at nothing; so I can not expect to come off even with them.

This was an extremely modest appraisal since he was to become one of the most successful of this new class of entrepreneurs.

\section{ANTEBELLUM SAN ANTONIO}

Although the city was experiencing considerable growth, the physical appearance was little changed from the mid-1700s until the 1850s. A visitor, Lewis Harvie Blair, related his impression thus (Wynes 1962:267):

In 1851, San Antonio was a mere village of adobe huts and American buildings of very cheap grade; with two plazas - one military, and the other civil, with a Mexican cathedral on the latter; a beautiful stream ... which, like Venus from the sea, sprung full-blown from the earth a few miles above the city....

The state of Alamo Plaza, in 1849, is vividly pictured in the annuals of the arrival of Dr. Ferdinand Herff $(1973: 27,34)$ and his wife to their new home:

Their entrance into Alamo Plaza was depressing after the delightful journey. The historic square lay muddy, covered with weeds, unkept 
Superficially prosperous, the city was undergoing an aftermath of depression related to the devastating cholera epidemic of 1849 .... Occasional attacks by hostile Indians and grossly inferior methods of sanitation further decimated the ranks of potential patients.

A major turning point in the development of the plaza was the occupation of the Alamo as the Quartermaster Corps for the United States army. This also prompted the construction of the Menger Hotel as a quality hostel on the plaza in 1857 (Everett 1975:116). This establishment became the center of activity for the growing influx of visitors into the area. Its brewery, catering to the increasing German immigration, became a social center drawing others to the neglected eastern bank of the river. The area soon acquired a predominately European cast. With the establishment of the German-English school in 1858 (Webb 1952 Vol. I:684) and the founding of St. Joseph's Church in 1868 (Gilbert 1949:29) the German flavor of the neighborhood was evident.

The presence of the army also spurred the growth of a second major east-west thoroughfare, Houston Street. Prior to the construction of the bridge, in 1851, Houston Street was named Rivas Street on the west running from San Pedro Creek to just beyond the San Pedro Acequia (Main Avenue). To the east, Paseo Street began at the river and extended to just beyond Alamo Plaza. With the move of the military headquarters to the Vance building, at what is now the corner of Houston and St. Mary's Streets, and the platting of the area north of the Alamo, by Samuel Maverick, as town lots, the area began to attract growth. Commerce Street, or Main Street, remained the major thoroughfare of the city (Fig. 3).

\section{THE CIVIL WAR PERIOD}

In March 1861, Texas, but not San Antonio, voted for secession, an event that was to have a pronounced effect on both the economy and growth of San Antonio. The first aspect was the total blockade of the Gulf Coast proclaimed by President Lincoln in April 1861 (Delaney 1955:474), forcing an immediate economic revolution. Items that had been traditionally imported from the northern industrial states were suddenly curtailed; such basic items as salt, guns, dishes, clothing, and medicines, had to be produced at home. Also the drain of able-body men to arm the Confederacy threw the burden of maintaining the home front upon the women, older men, children, and slaves (Fehrenbach 1968:356-357). These conditions brought the growth of the frontier almost to a halt.

The second, contrasting effect of the blockade was the new source of wealth that it would bring to some. The blockade was to virtually eliminate the flow of cotton required by European and northern textile mills. In England alone some four million were dependent upon southern cotton for their livelihood (Delaney 1955:475). This demand, coupled with its escalating value due to supply and demand, created a vast trade in cotton into the free ports of Mexico, protected by the delicate international situation with the adjacent neutral nation (Sibley 1973:40). Early in 1863, it was reported that from 180 to 200 ships of all nations (including the United States) lay at anchor off the mouth of the Rio Grande waiting to discharge cargo and receive cotton (Delaney 1955:483). This vast network of trade would all pass through San Antonio (Kerby 1972:178-179):

By June 1864, traffic through the town became so dense that the city council was forced to levy a tax on each bale carried through its streets to cover the cost of road and bridge repairs and to pay for the removal of hundreds of animal carcasses abandoned by the wagon trains.

\section{THE RECONSTRUCTION PERIOD}

The years following the Civil War were bitter times for Texas, as well as the entire South. The economy was a shambles and its citizens broken and demoralized.

The economy and future of Texas lay in ruins. Fully one-fourth of the productive white male population was dead, disabled, or dispersed. Almost every form of real wealth, except the land itself, was dissipated or destroyed (Fehrenbach 1968:394).

The problems of recovery were further compounded by the excesses of the "Carpetbagger" regime imposed upon Texas by the northern military control. The "ironclad" loyalty act disenfranchised any who had ever been "a mayor, school trustee, clerk, public weigher, or even a cemetery sexton" from public office (Fehrenbach 1968:410). This 


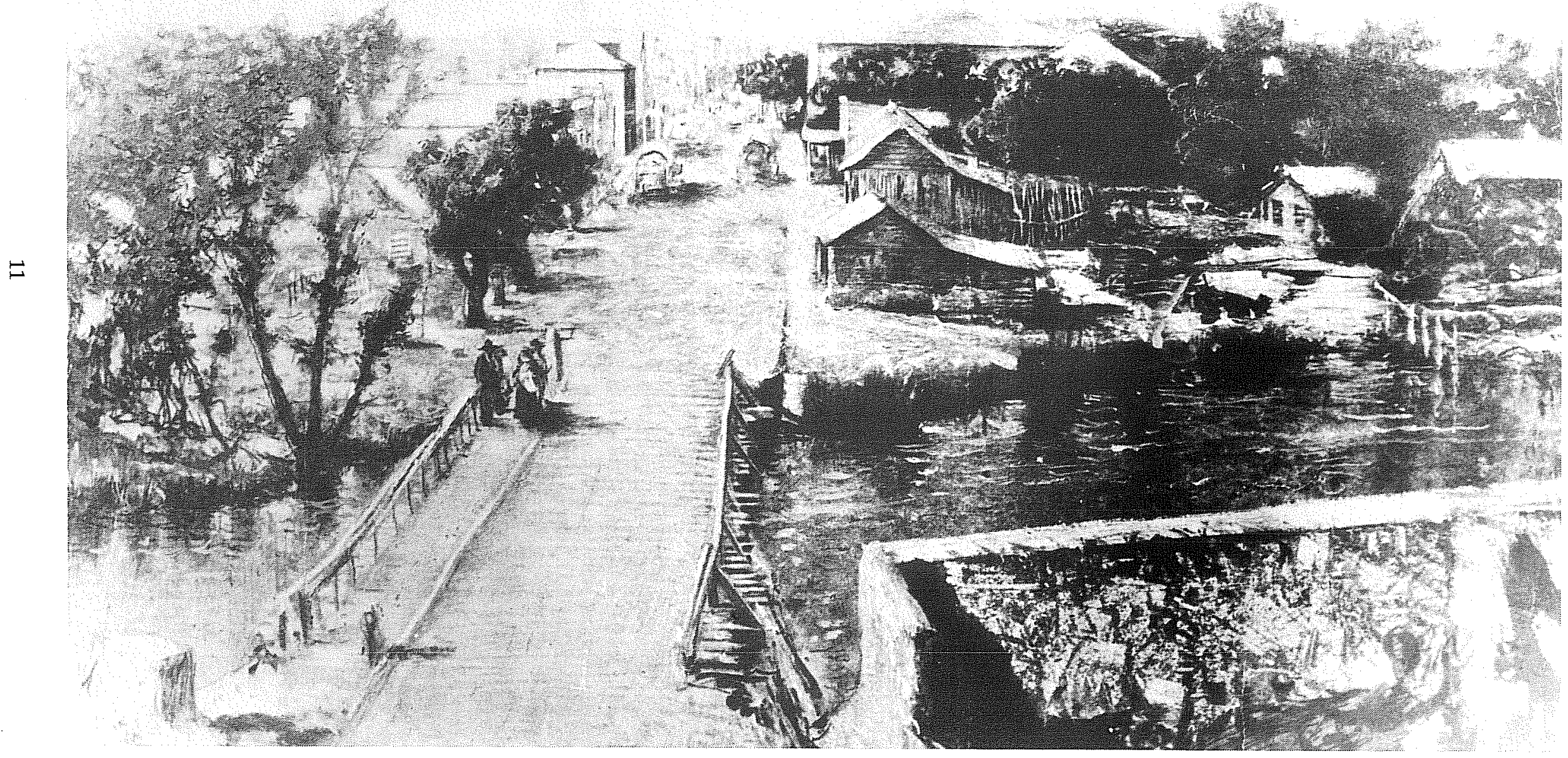

Figure 3. Commerce Street, ca. 1861. View is looking west from the bridge. Courtesy of the Daughters of the Republic Research Library, The Alamo. 
school trustee, clerk, public weigher, or even a cemetery sexton" from public office (Fehrenbach 1968:410). This resulted in the military appointment of often grossly incompetent and corrupt public officials. San Antonio, as a whole, was to fare much better during this trying period than the majority of the state, due to several unique circumstances. First, because of the neutrality, or outright Union support, of many of its leading citizens, there were several well-qualified and experienced candidates for public office available for the military to draw upon. Wilhelm Carl August Theilepape, an educated and qualified Unionist, was appointed mayor, in 1867 , by General J. J. Reynolds, the federal authority in Austin (Corner 1890:67). He was to serve capably until 1872 .

A second major factor was the return to San Antonio of the U.S. army. Although now an army of occupation, it was, none the less, a source of "greenback" money for the local economy as the flow passed through the area to restaff the frontier forts, serving in some measure to ease the Indian problems (Fehrenbach 1978:103).

The third, and probably the most important to the city, was the growth of a new industry - the cattle drives that arose to supply the beef-hungry north. San Antonio, as the only major city of the vast frontier, as it had been for the cotton trade, was the primary benefactor of this new source of capital. Rough and tumble San Antonio became the capital city of the short-lived cattle empire (Fehrenbach 1978:107).

Yet these were still hard times beset by many problems. Funds for city improvements were nonexistent. The gas works, established in 1859, lay idle due to lack of operating money. The streets were dark and rough, and in bad weather almost impassable, with vehicles remaining mired for days. Trash and garbage filled the yards and streets (Morgan 1961:49).

A major problem was the antiquated water system. Water was still obtained from shallow wells, cisterns, and the acequia system, just as it had been from the days of the Spanish padres. Most of these were contaminated by the casual introduction of filth and seepage from the ever-present outhouses (Morgan 1961:50).

The habit of depositing cats, and other luxuries that the citizens have no further use for, in the stream [San Antonio River] coupled with the inability of the slow current to transport them outside the city limits until they have become infirm with age, has done much to make cistern water popular (Sweet and Knox 1905:309).
As a result of these conditions, in 1866, cholera became epidemic in San Antonio. While not as severe or extensive as in 1849, 198 deaths were recorded in the last 12 days of September and 112 for December (Nixon 1936:136). The need for an improved water system and sanitation had long been recognized and promoted by physicians and the Public Health Board. In fact, it was the public outcry at the attempt by Mayor Theilepape to purchase the headwaters of the San Antonio River from George Brackenridge that prompted his ouster from public office (Sibley 1973:129). In 1873, George W. Maverick proposed an active program for a public water works system. The proposition failed due to the continuing monetary problems and the national financial panic in the United States (Morgan 1961:53). In 1875, a second attempt was initiated by H. B. Adams only to meet equal opposition (McLean 1924:5). The availability of proper sanitation and healthful water was to succumb to what most considered a more important and tangible economic reality.

Vinton Lee James, son of an 1837 settler of San Antonio, detailed description of Commerce and Houston Streets paints a vivid picture of the area during the mid to late 1800s (James 1938). By 1873, the majority of the commercial buildings of the city were concentrated on Commerce and Market Streets and Main Plaza. Houston Street was primarily residential with a few commercial buildings scattered along the area. St. Mary's Street only extended between the northern river loop with a foot bridge to the south. Alamo Plaza was mixed, commercial and residential. There were only two vehicular bridges, on Commerce and Houston Streets. The other two foot bridges were located at Navarro and Presa Streets. The foot bridge at Presa Street was to the east of the main ford of the city. The two small bridges rested on stone abutments built on a river island and were chained in such a manner as to allow the structure to swing free during times of flooding (San Antonio Express 1927:2D).

\section{THE "GOLDEN AGE" OF SAN ANTONIO}

In 1875, San Antonio was the only major city in the nation that was not serviced by a major port or railway. All goods, still primarily supplied from the north, had to be transported over admittedly inferior roads to supply a city that had now fallen to Galveston as the most populous in the state. It was openly apparent that San Antonio could no longer aspire to grow, much less maintain its distinction as 
a major western terminus, without the advent of rail transportation. The city had already seen its title of cattle capital usurped by the introduction of the iron rails into the state. The railroad was the link to both today and tomorrow that was imperative as its gateway to the industries of the east and the growing markets of the west. Most of these visions were to prove inherently realistic. The arrival of the Galveston, Harrisburg, and San Antonio Railroad, on February 19, 1877, was greeted with pomp and splendor unprecedented in all of San Antonio's often flamboyant past. Heralded as "the greatest incident connected with the history of our city" (San Antonio Daily Express 1877:1), thousands cheered its entry into the new terminal only three blocks from the Alamo.

The entry of rail transportation to the city was without question one of the major factors in transforming the raw frontier town into a newly emerging city. It thrust it into the new "Golden Age" of America. Now San Antonio was forced to face the image it was projecting to the nation.

\begin{abstract}
When the railroad entered San Antonio, there was no sewer system or drainage except the river, no sidewalks and a great deal of mud, even during dry weather, because of the overflow of the irrigation ditches which still were the principal source of water supply (Morgan 1961:55).
\end{abstract}

Ready to meet this challenge was one of the city's more forceful mayors, James Henry French. Elected in 1875, he was to hold the office continuously for the next 10 years. Under his administration, action was initiated to improve the streets, develop public transportation, establish fire departments, and rename and number the tangle of streets, allowing the first implementation of mail delivery (San Antonio Express 1939:7).

The necessity of supporting the new growth of the city again brought the question of the water system into the public consciousness. In April 1877, the city gave a contract to Jean Batiste Lacoste and associates to supply water to the city from the head of the river, which was completed and accepted by the city July 5 , 1878. Yet the public was reluctant to change their old habits, and acceptance of the system was disappointing. In 1883, the company sold to George W. Brackenridge (McLean 1924:6).

The works took a new lease of life under Mr. Brackenridge. With a serene faith in the future of the city he has yearly put and advised his company to put thousands upon thousands of dollars underground until today the city has a vast network of iron pipes (Corner 1890:55-56).

The anticipated growth caused by the introduction of the iron rails soon became a reality. The population increased from 17,314 in 1876 , to 20,550 by 1880 , and was destined to rise to 37,673 by 1890 , an increase of $117 \%$ (USDI-OC 1880, 1890; Fehrenbach 1978:117). This surge was comparable to the rapid growth experienced during the pre-Civil War period. However, the newcomers this time were no longer predominately European, but instead were primarily families from the South (Fehrenbach 1978:123). Prior to this influx of growth, it was generally agreed that the "Germans" ran the town, not necessarily the wealthiest, but the "solid, stolid, stable element" (Fehrenbach 1978:121). A major manifestation of this presence was the growth of the King William area, a short distance to the south of Alamo Plaza. With the new expansion, the older families constructed lavish new homes within the area, their architecture was, however, not German, but rather "early Victoria" with a few modifications (Burkholder 1973:10-11).

The arrival of rail transportation was also to make a major impact upon the architectural style of the entire city. Prior to the late 1870 s, the primary construction materials were caliche and limestone block, but with the introduction of inexpensive transportation cost for materials too heavy or bulky for overland shipment - brick brought from the east, and later the west, became a popular and preferred material (Morrison and Fourmy 1881). This was further promoted by the establishment of local brick companies, capitalizing on the increased demand. In addition to local production, no less than 190 carloads of brick were transported to San Antonio by rail in 1884 alone (Land and Thompson 1885:38).

Another innovation during this period was the introduction of a new building material from a local source. William Lloyd, an Englishman on a hunting trip north of the city, discovered a distinctive calcified rock. An analysis by George Kalteyer, one of the towns leading druggists and chemist, revealed that it was an excellent cement rock, resulting in the establishment of the Alamo Cement Company in the quarry, present-day Sunken Gardens in Brackenridge Park (Odom and Young 1985:50).

The railroad was destined to open yet another major market for San Antonio, the wool trade. With the arrival of transportation facilities, the wool route shifted from New Braunfels to San Antonio. The opening of the International and Great 
Northern Railway to west Texas, in 1888, opened vast new markets, and wool became a major commodity of trade, with up to $10,000,000$ pounds of wool received in a single year (Morrison 1891:69). The receipts of 1884 reflect $7,000,000$ pounds received, and in 1890 , shipments of $6,000,000$ pounds were valued at a prevailing market rate of $\$ 1,200,000$ (Land and Thompson 1885:32).

In 1885, the city elected a new mayor, Bryan Callaghan, son of an Irish immigrant who married into one of the city's original Spanish families. In cooperation with his political machine, "King" Callaghan was to control San Antonio for the next 30 years. While some claimed that he ran the city for "gamblers, riff-raff, and crooks," others "considered him more of an asset than the Alamo" (Morgan 1961:67). Although San Antonio now had a modern water system, it still had major sanitation problems, and it was not until 1890 that Mayor Callaghan could report that the city now possessed 29.5 miles of graveled streets, but these remained in poor condition because repairs had not been made soon enough (Morgan 1961:68). It was not until after 1900 that local inhabitants began building indoor bathrooms in new homes (Morgan 1961:92).

Throughout the city these waves of modernization were evident. Starting in 1878, San Antonio was linked by four systems of mule-drawn public trolleys, to be replaced in 1890 by electric-powered coaches (Corner 1890:6; Fehrenbach 1978:129). George Brackenridge received the first telephone line in 1881 , and the following year the system connected 200 subscribers (Odom and Young 1985:54). By 1887, an efficient electric power plant was in operation (Fehrenbach 1978:129). Banks and breweries flourished, and in 1888, the new Joske's store was established at the corner of Alamo and Commerce Streets (Odom and Young 1985:48). By 1900, the population had reached 53,321 , a substantial city at the turn of the century (USDI-OC 1900). During the period between 1879 and 1892, many of the landmark buildings of downtown San Antonio were constructed: the original Groos bank (1879), the Crockett block (1882), City Hall (1889), the Clifford building (1890), the Turn Verein (1891), and the Chandler building (1892). During the years between 1895 and 1899, there were some $\$ 3,000,000$ worth of buildings constructed in the city (Appler 1897, 1899).

Yet, San Antonio had not entirely abandoned its colorful past. It was known as the "flashy, sin-dazzling metropolis of the Southwest." Evangelist Dixie Williams thought "San Antonio is the wickedest city in the Union, not excepting Washington City, which is the wickedest out of Hell" (Morgan 1961:62-63).

\section{THE 20TH CENTURY}

As the new century dawned, San Antonio emerged as a great city, largest and grandest in the state. Cattle millionaires and the military complex at Fort Sam Houston gave the area economic stability (Fehrenbach 1978:149). But a shift in the development of the downtown area was creating a problem for one of San Antonio's major thoroughfares and its wealthiest merchants.

Commerce Street had long been the principal street of the city, the major connecting artery between the east and west sides of San Antonio, and the site of the most important businesses, merchants, and banks. But, when the idea of streetcars was introduced, conservative Commerce Street did not want the disturbance introduced into its midst, and the streetcars were restricted to any other street in the city. The same stipulation was included when the new electric streetcar system began (Fig. 4). In consequence, the streetcar traffic was carried to Alamo Plaza, Avenue C (Broadway), and Houston Street, with the increased growth that was to be expected.

In 1905 , the city council proposed a downtown improvement district for the purpose of widening Houston and Commerce Streets. Fearing that widening Commerce Street would prove impractical and too expensive, the Commerce Street merchants demanded, and obtained, their own district. As a result the lower part of Houston Street was widened, and Commerce Street was merely paved. Thereafter, Houston Street experienced a boom in growth at the expense of Commerce Street (Deutschmann 1915:19-21; Fig. 5).

Realizing the seriousness of the decline, a committee was formed to address the problem. The problems were viewed as three-fold: the lack of streetcar transportation, the narrow width of the street, and the lack of cross streets and access into the avenue. Commerce Street could not benefit from the south because access was prohibited by the Arsenal and "little streets like Yturri and Corcoran, South Presa and Casino which begin nowhere and end nowhere, are not feeders to Commerce Street" (Deutschmann 1915:25). On the north there were only Losoya, Navarro, Soledad, and St. Mary's Streets. Losoya and Soledad Streets were too narrow for practical traffic use, and St. Mary's Street terminated on the north side of the street. The only salvation was to widen the street to 65 feet by taking out the buildings on the south side. The only exception was the new five-story Alamo National Bank building, which was elevated and 


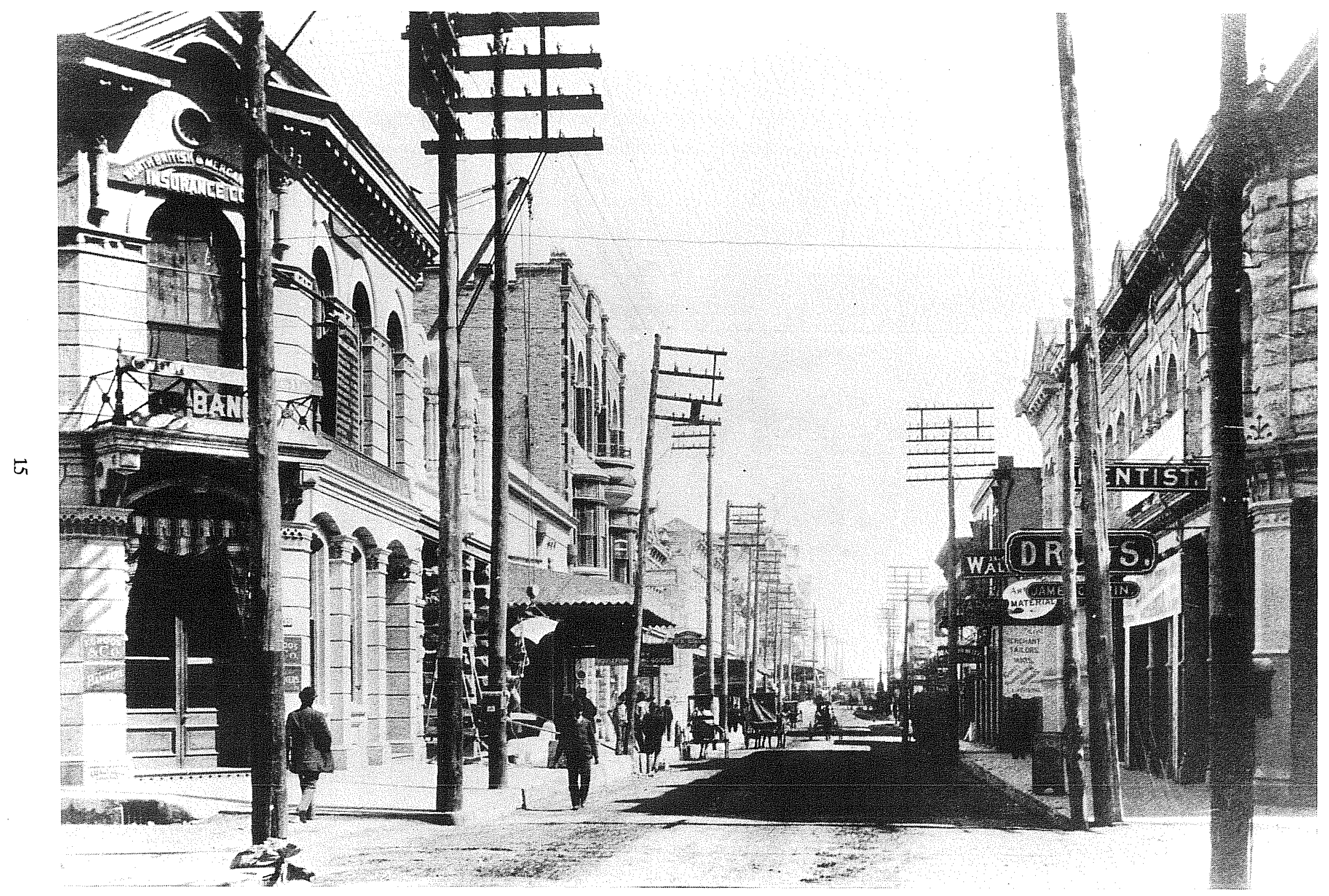

Figure 4. Commerce Street, ca. 1900. Looking east from Navarro Street prior to widening. Courtesy of the Daughters of the Republic Research Library, The Alamo. 


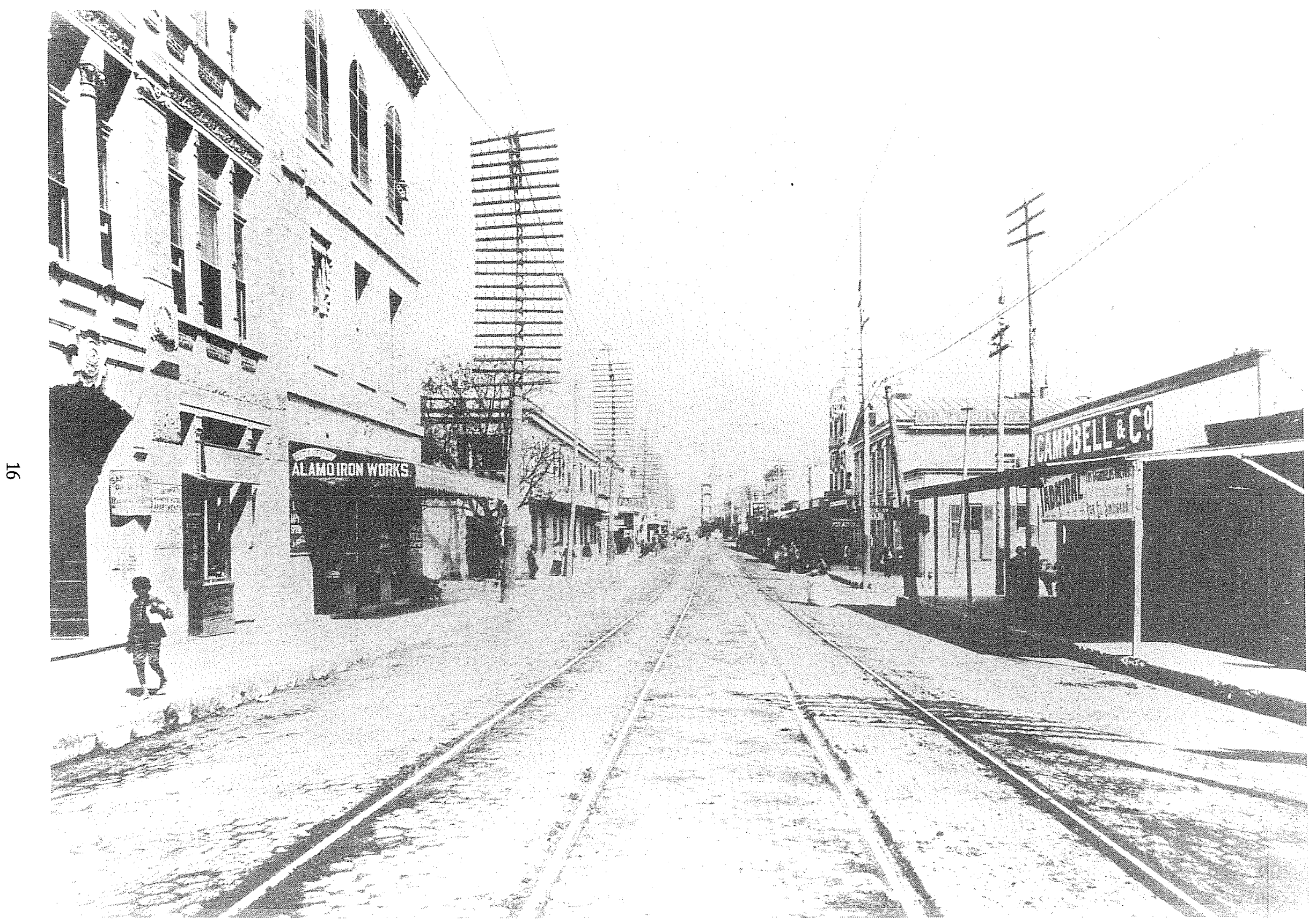

Figure 5. Houston Street, ca. 1900. Looking east. Note the streetcar tracks and wooden pavers. Courtesy of the Daughters of the Republic Research Library, The Alamo. 
moved back beyond the new street line. All this was accomplished in 1915 (Fig. 6).

San Antonio continued to grow, and the advent of the automobile encouraged development of the fashionable subdivisions to the north. The west side remained predominately Hispanic, and the south side expanded with the homes of tradesmen and blue collar workers. The east side fostered a small community of Blacks. The impetus of the city's growth remained a result of mercantile, military, and as a distribution center. There was little industry and no base from which it could develop (Fehrenbach 1978:155). These elements created a prosperous, stable, but stagnate culture during the first decade and one-half of the new century.

The catalyst for the final factor to bring San Antonio fully into the modern world was the advent of World War I. In 1910, Lt. Benjamin Foulois was assigned to Fort Sam Houston to initiate aviation operations in Texas' favorable weather. San Antonio's future in military aviation was launched March 2, 1910, with Foulois's take-off from the Fort Sam Houston parade ground (Fig. 7). In 1915, now captain in charge of the First Aero Squadron, Foulois led aerial reconnaissance for General John J. Pershing in search of Pancho Villa (San Antonio Express-News 1986:49P). With the nation's entry into World War I, Texas became the primary training ground for more than 250,000 infantry men and fliers (San Antonio Express-News 1986:58P).

During the 1920s, the city continued its growth. For a short period, it was the expatriate home for 25,000 wealthy refugees from the Mexican Revolution, and the permanent home for thousands of others (Fehrenbach 1978:169). San Antonio became the center for the Mexican presence north of the border.

In September 1921, San Antonio experienced another of its devastating floods with a lost of 49 dead, 14 missing, and an estimated $\$ 8,000,000$ in property damage (Corps of Engineers 1972:5). This would, at last, spur positive action to correct this recurrent hazard. Channel improvements, which began with the construction of Olmos Dam and the rechanneling of the downtown river bend, continue until today.

By 1930 , the population reached 231,542, enabling San Antonio to retain the title of the state's largest city. San Antonio began to awaken to the realization of the dangers of progress to its historic heritage, an awakening that stirred a multifront effort to save and preserve its past. Some of the results of these efforts are San Antonio's major assets of today: the Riverwalk, La Villita, the Spanish Governor's Palace, and Mission San José.

The national Depression caused a long period of stagnation that settled upon the agrarian sector, depressed business, and drastically cut into the military spending to which San Antonio had grown so accustomed. During this period, and for the following decade, San Antonio slumbered. By contrast, Dallas took charge as a financial and mercantile capital, and Houston exploited its wealth of mineral riches, and in turn, both surged ahead of San Antonio in population (Fehrenbach 1978:173).

This hiatus was abruptly ended by the nation's entry into World War II. Again military activity would rise to revitalize both the economy and the enthusiasm of the city. With this firm financial base, San Antonio began to reemerge as a growing metropolis.

The greater San Antonio
metropolitan area, now 1 million in
population, looks to a future of
continued national importance, an
attractive image of a city in the sun, an
example of well-planned growth, a
city where endeavors as diverse as
agribusiness and electronics prosper
together (Odom and Young 1985:31).

\section{POTENTIAL ARCHAEOLOGICAL SITES WITHIN THE PROJECT AREA}

Prior to the initiation of construction, the project managers were supplied with a report of important historical remains that could be impacted by the anticipated modifications. These were addressed under three major categories: National Register Historic Districts, Texas Revolution fortifications, and portions of the acequia systems of San Antonio.

The Tri-Party project area included three of the six areas in San Antonio designated as historic districts on the National Register of Historic Places (Fig. 8). Established under the National Historic Preservation Act of 1966 as "a catalog of a major part of the heritage of the American people," a historic district is defined as "a geographically definable area, urban or rural, with a significant linkage or continuity of sites, buildings, etc., which are related historically or esthetically" (Steely 1984:iv).

Evidence of any of the following historic sites was likely to be encountered where modifications were expected to penetrate more than 12 inches below the present surface; therefore within the sensitive areas indicated, the archaeologist should be on-site to monitor whenever construction was in progress. 


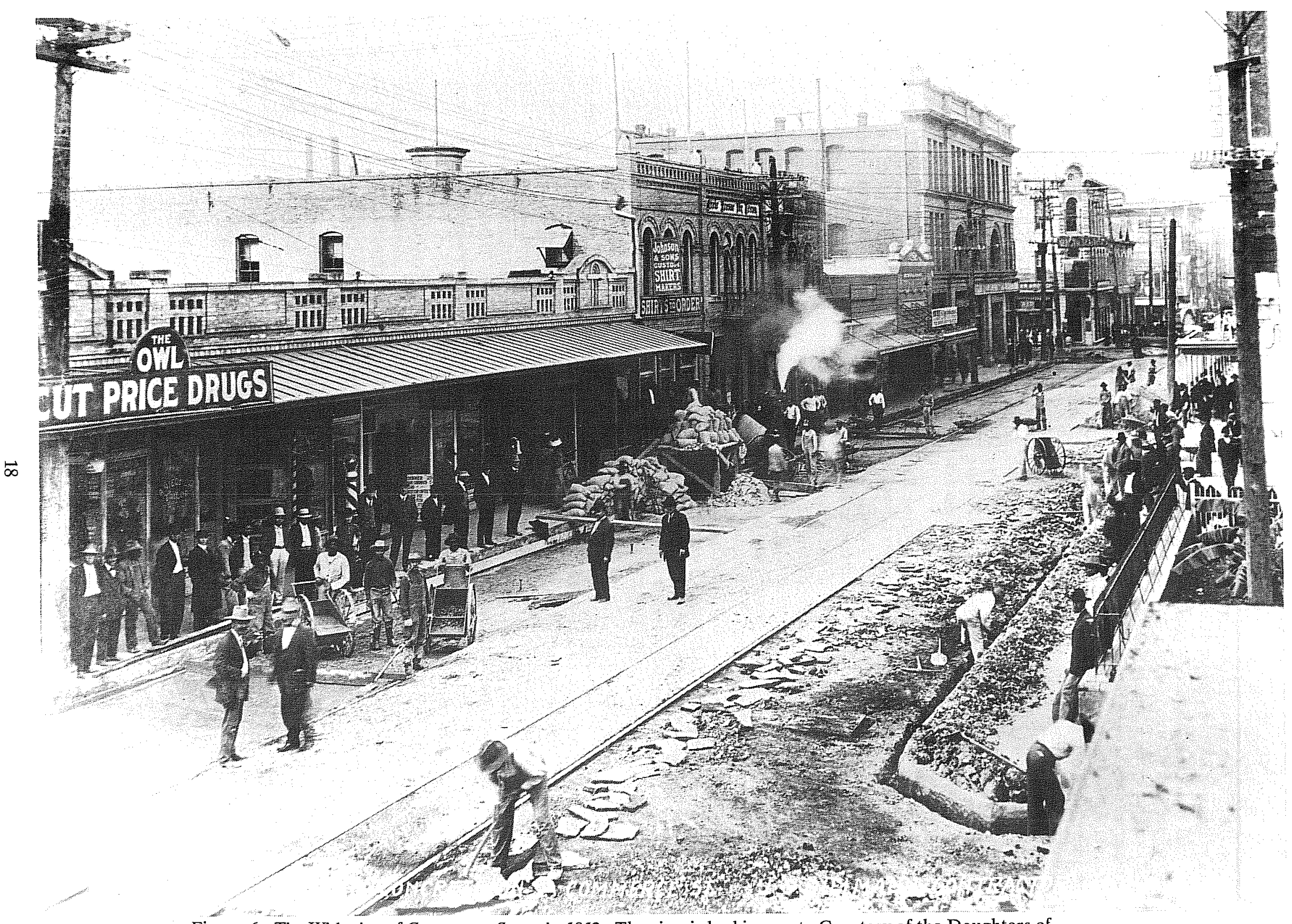

Figure 6. The Widening of Commerce Street in 1912. The view is looking east. Courtesy of the Daughters of the Republic Research Library, The Alamo. 




Figure 7. Lt. Foulis at Fort Sam Houston, 1910. Standing in front of the Wright Flyer, the army's first airplane. Courtesy of the Institute of Texan Cultures, The University of Texas at San Antonio. 


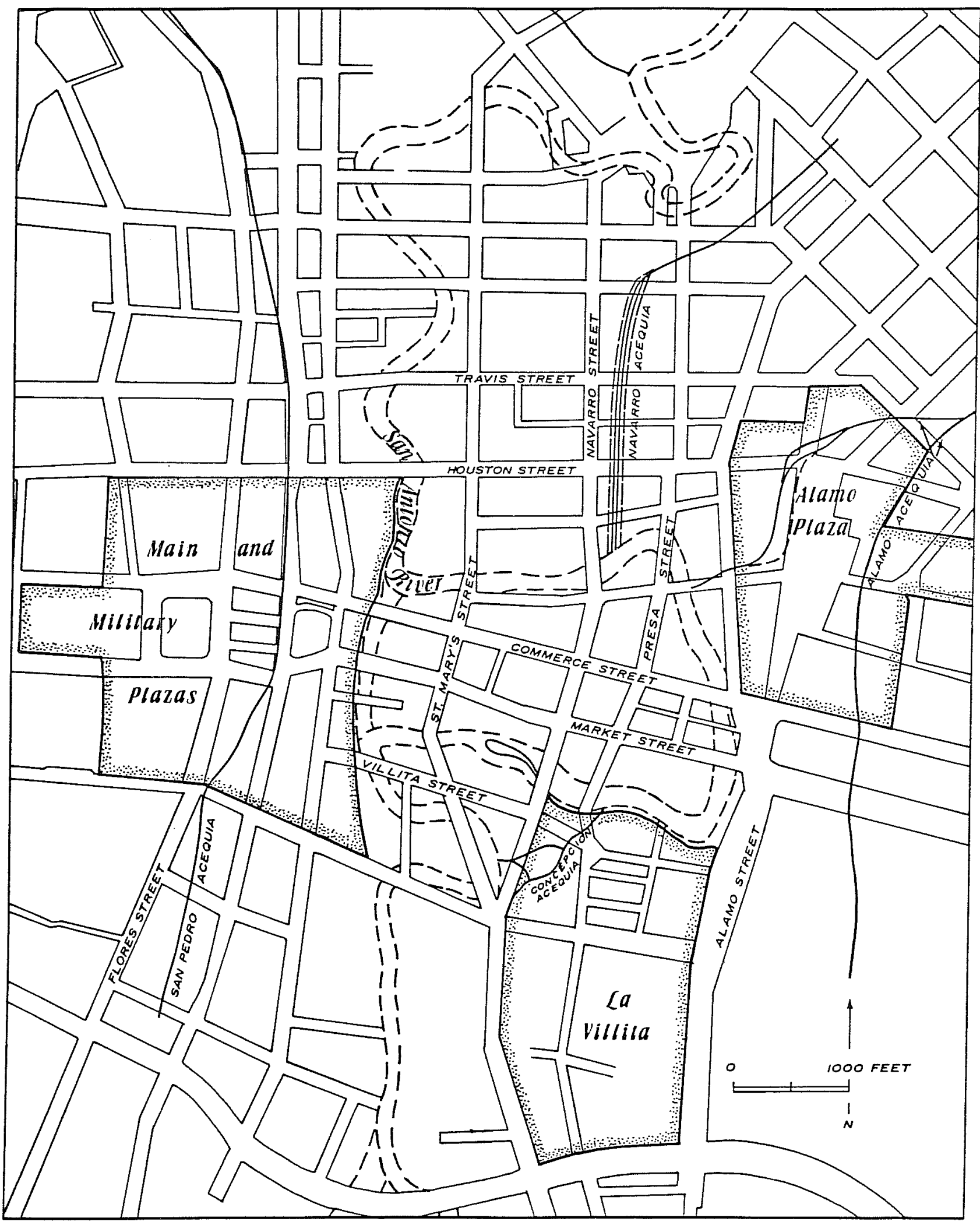

Figure 8. Historic Districts within the Tri-Party Improvements Area. 
Alamo Plaza Historic District

The Alamo Plaza Historic District was placed on the National Register in 1976, this district contains parts of 10 blocks with 22 historic and 27 compatible structures. It is located around Alamo Plaza on lands once part of the mission grounds.

\section{La Villita Historic District}

La Villita Historic District consists of 27 buildings reflecting Spanish, Mexican, European, and 19th-century Anglo-American influences. La Villita was restored in 1939. The area was added to the National Register in 1972.

\section{Main and Military Plazas Historic District}

Main and Military Plazas Historic District consists of 13 blocks with two plazas. Long the center of activity in downtown San Antonio, this area has been the scene of numerous historic events. National Register status was granted in 1979.

\section{Texas Revolution Fortifications}

Prior to the siege of Bexár in 1835 and during the battle of the Alamo in 1836, several field fortifications were established at various locations throughout the city. Several probable locations of these sites were identified within the project area (Fig. 9). The nature of both primary and secondary sources preclude determination of the exact location for any of these installations. Therefore, only an approximate area could be identified.

\section{The Acequia System}

The acequias, or irrigation ditches, were a vital factor in the Spanish plan to establish the villa of San Antonio de Bejár. For this reason, construction was begun on the first acequia in 1718 at the same time the first mission (San Antonio de Valero) and the presidio were established. Construction of acequias continued through 1875. These acequias developed into a vast complex of channels throughout the San Antonio River valley. One acequia still irrigates the lands near Mission Espada. Portions of four acequias were within the project area (Fig. 8).

\section{San Pedro Acequia}

The San Pedro Acequia began at San Pedro Springs and supplied water to the presidio and villa, as well as to the lands to the south of the plaza. The original channel was an unlined ditch, but by the 1850 s the downtown portion was lined with cut limestone (Cox 1986:2-3). The acequia entered the project area on the west side of Main Avenue as it crossed Houston Street (Fig. 10). It was anticipated that the acequia would cross the entire width of Houston Street and would be stone lined, unless entirely destroyed by previous utility and street construction. The next two encounters were expected to occur on the west side of Main Street at Commerce and Dolorosa Streets, with the channel curving to the west on Dolorosa Street to enter New City Block (NCB)100 (Fig. 11). The channel was anticipated to be lined throughout the area.

\section{Alamo Acequia}

The Alamo Acequia was begun in 1724 near the headwaters of the San Antonio River and extended along what is now the east side of Broadway Avenue to near the intersection of Nacogdoches and Elm Streets. There it divided into two channels. The western branch flowed toward the grounds of the Alamo (Cox 1985:2) and entered the project area north of Houston Street (Fig. 12). It further divided north of Travis Street, with the eastern branch entering the Alamo grounds behind the chapel, while the western branch continued parallel to Houston Street north of the compound wall of the mission (Fig. 12). Near the northwest corner of the mission wall, the western branch turned southward.

The dashed line on Figure 12 represents the original path of the acequia as it flowed through the Indian quarters within the compound. The exact position of this ditch cannot be accurately determined due to lack of documentation in any known historical records. Since it was contained within the limits of the mission property, it was never a factor in land distribution, and it ceased to flow after its diversion outside the west wall in 1835 . The solid path of the acequia on Figure 12 indicates its position after its diversion by General Cós in 1835, when he converted the old mission complex into a fort (lower line on Fig. 12), and Sam Maverick's later realignment (upper line on Fig. 12) sometime after he acquired the property in 1849 (Green 1921:108). Reports of the excavation of the basement of the Gibbs building, on the eastern portion of NCB 422 in 1908 and archaeological 


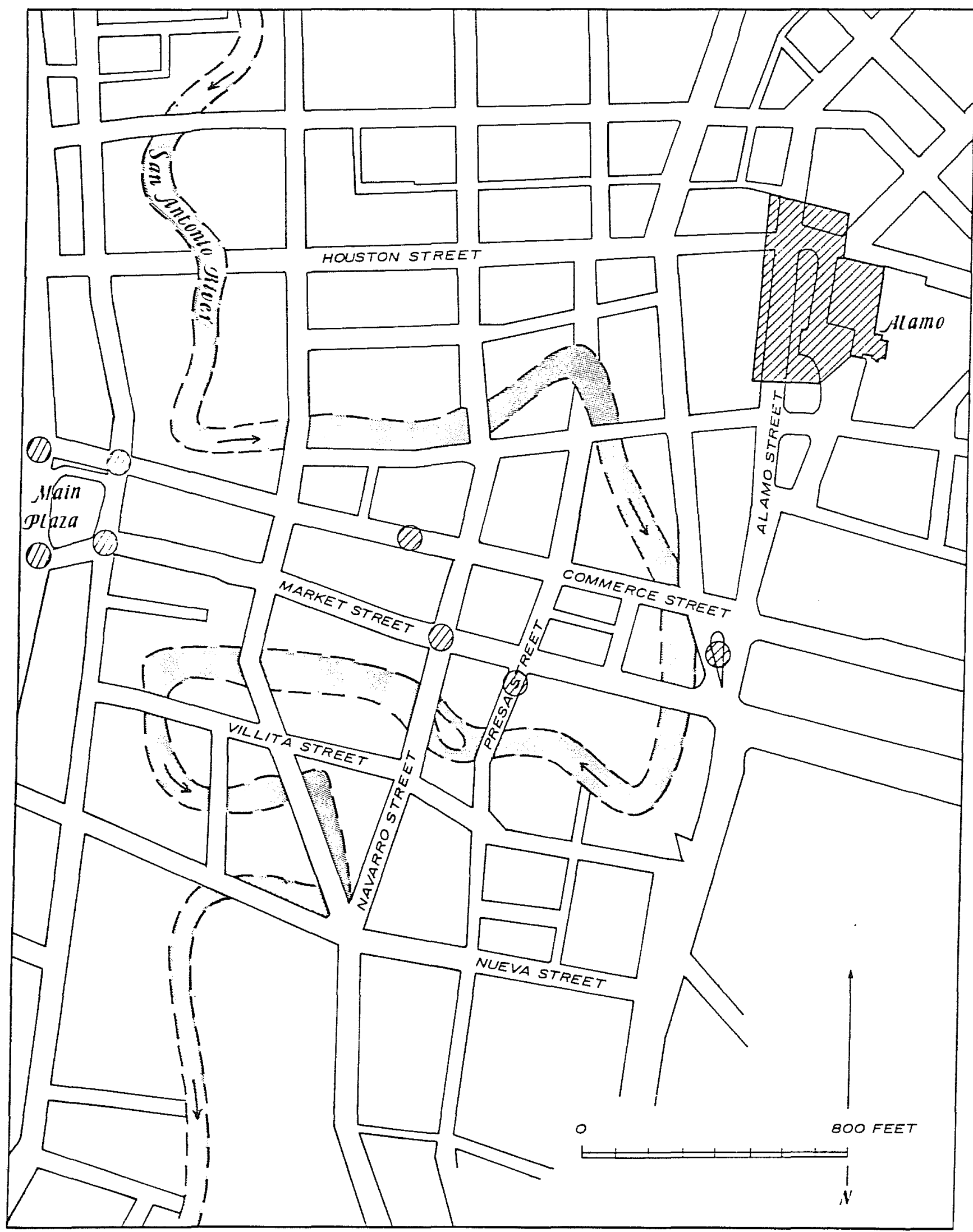

Figure 9. Texas Revolution Fortifications. 


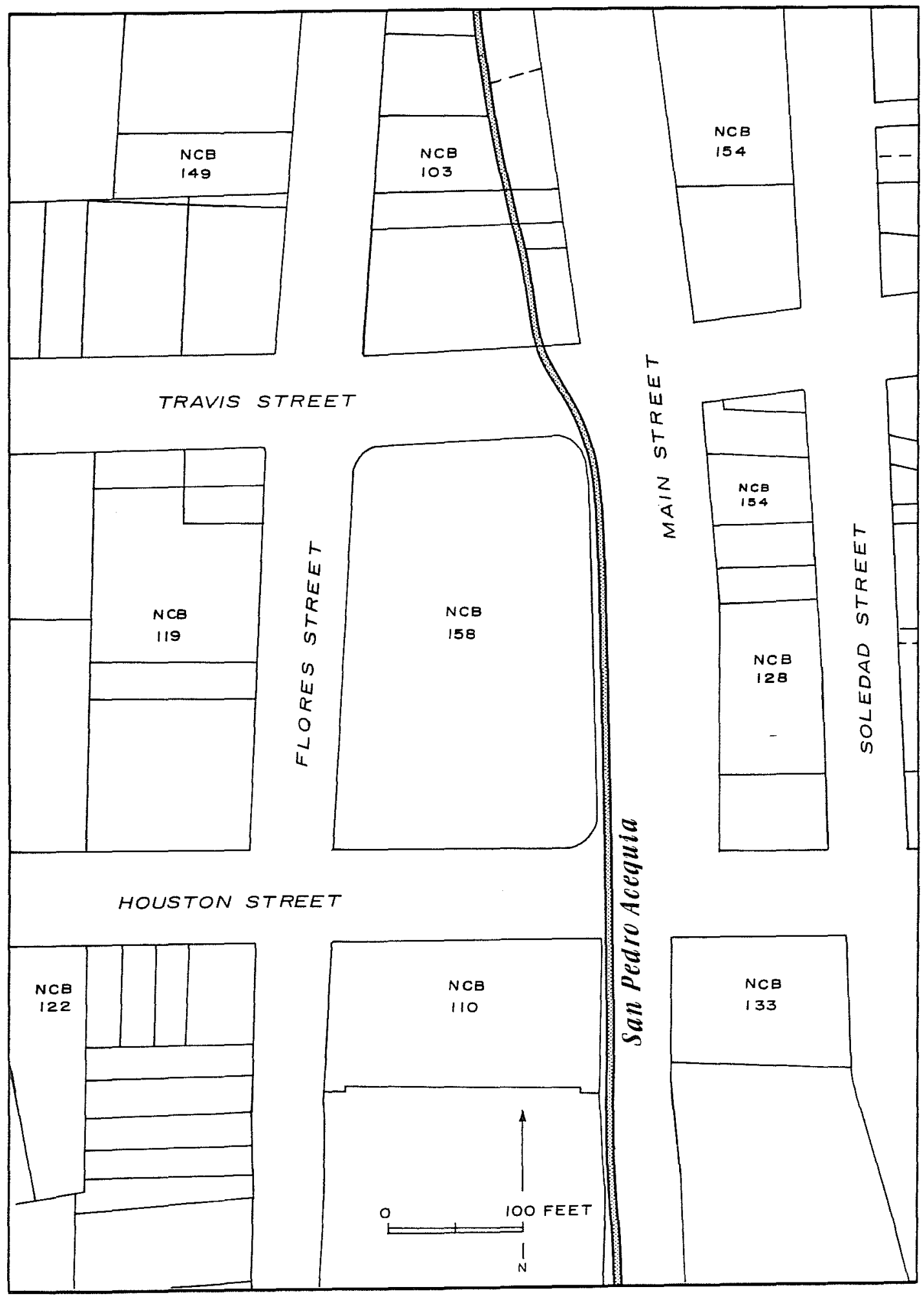

Figure 10. San Pedro Acequia at Houston Street. 


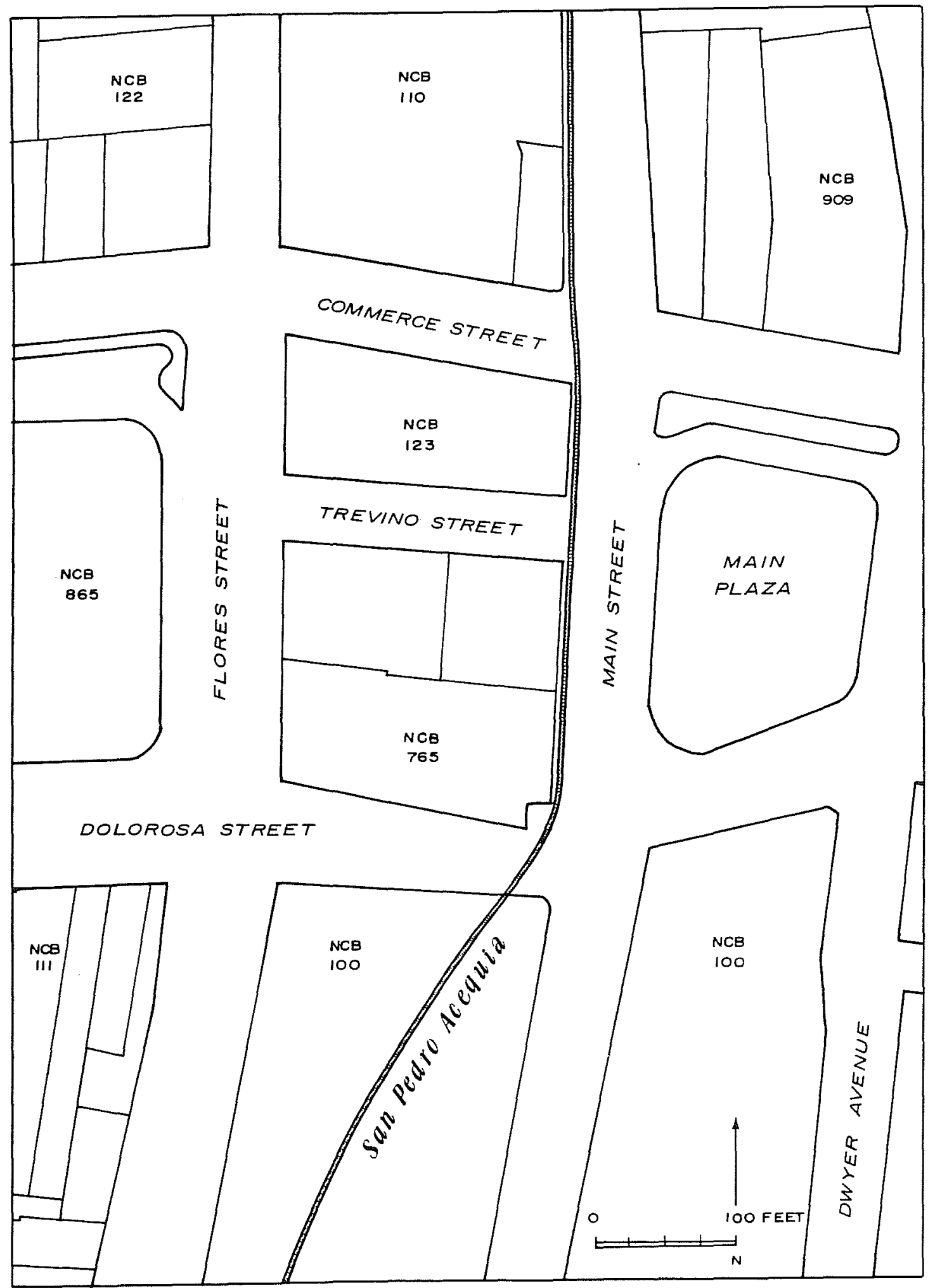

Figure 11. San Pedro Acequia at Dolorosa Street. 


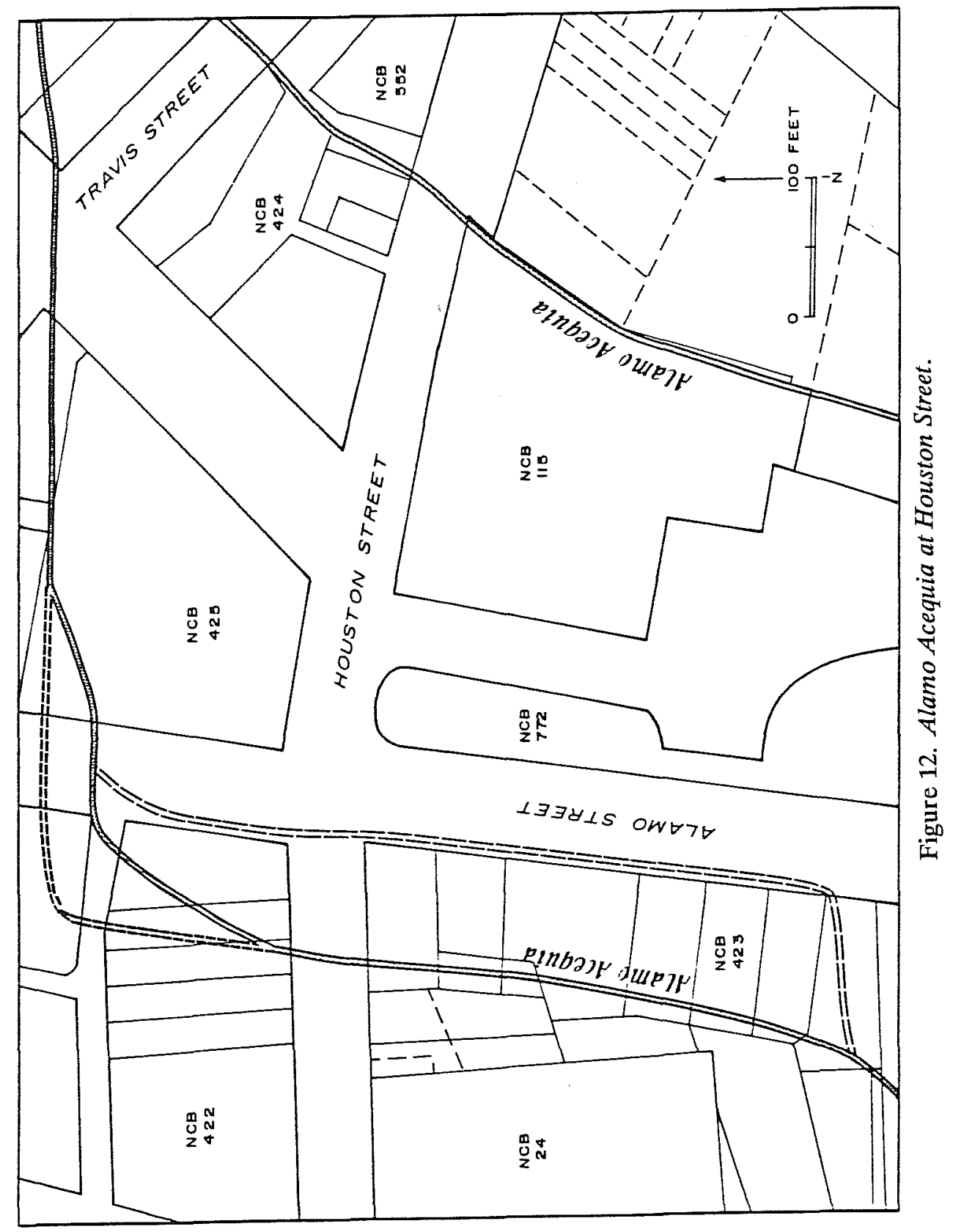


investigations in 1979 by the CAR in NCB 423, indicate that the ditch was unlined within this area (Steinfeldt 1978:162; DRT n.d.; Center for Archaeological Research files). The same ditch, still unlined, may be encountered as it crosses Losoya Street and enters Crockett Street on its return to discharge into the river (Fig. 13). The previously mentioned eastern branch, after leaving the grounds of the Alamo in NCB 115, was expected to cross both Crockett and Blum Streets to the east of Alamo Plaza (Fig. 14). Although this ditch was stone lined at both crossings, previous observations of utility trenching in these streets by CAR personnel indicate that any vestiges of its course have been destroyed or severely disturbed by utility and street construction.

\section{Navarro Acequia}

The existence of the Navarro Acequia is considerably less well documented than the other acequias of the system. The first documentation of its location appeared in 1850 when the acequia at its southern end, actually two parallel ditches separated by 13.8 feet, appeared as a property line for lands of José Antonio Navarro (City of San Antonio 1850 Vol. 1:111). Other land division maps, however, support contentions that it existed in 1793 when the mission lands were distributed to various individuals. The location where the parallel ditches crossed Houston and College Streets is purely conjectural, and therefore the dashed lines on Figure 13 indicate the probability of the area for the placement of the acequia.

\section{Concepción Acequia}

The date of the construction of the Concepcion (or Pajalache) Acequia has never been reliably determined. It is generally claimed that the acequia was initiated in 1729. However, it could have been constructed as early as 1720 , if its intended purpose was to serve the first site of Mission San José y San Miguel de Aguayo. The ditch originated at its dam on the San Antonio River on the northern edge of $\mathrm{La}$ Villita. The primary concern within the project area was the branched desague (discharge or flood channel) from the main ditch that crossed Navarro Street below Villita Street (Fig. 15). Of lesser concern was the main channel of the acequia near the eastern side of the juncture of South St. Mary's and Navarro Streets, because records indicated that its depth at this point should be below the level of anticipated modification. Both channels should be unlined within this area.

\section{METHODOLOGY AND MONITORING}

Active monitoring of the Tri-Party construction effort began with the official ground-breaking ceremonies on Commerce Street June 24, 1988. Five days later the first evidence of a historic structure was encountered at the corner of Navarro and Market Streets. Trenching operations uncovered a foundation of soft yellow brick bonded with cement mortar running parallel to the south side of Market Street (Fig. 16a). Research revealed that the structure was the warehouse of Meyer and Soloman Halff, a wholesale dry goods firm founded prior to 1879 on Commerce Street (Moody and Morrison 1879). On May 29, 1897, Meyer Halff purchased the property in question from the estate of Theodore Heermann. At that time, the three-story 30- x 40-foot building was already present ( $D R$ Vol. 160:188). In 1905, the building served as the wholesale hat outlet for Emanuel Longini, a traveling saleman for the Halff brothers (Appler 1905). The building was probably destroyed in 1936 when Market Street was widened (San Antonio Light 1936).

On July 18, the project began excavation with a Deere 990 excavator of a four-foot-wide trench along Alamo Street, beginning just to the south of the Blum Street intersection. Encountered was a layer of creosoted brick-shaped wooden blocks immediately below the asphalt paving. These blocks, generally referred to as mesquite, but in fact are primarily pine, were used to pave the majority of the downtown streets beginning in 1889 (Schuchard 1951:37). Shortly thereafter, streetcar rail set into an 18-inch-thick concrete base was encountered. The streetcar system for San Antonio was initiated in the fall of 1877 under the direction of Colonel August Belnap (Everett 1975:144). Below that level the subsoil was almost entirely disturbed by various utility trenches over a period of many years. This disturbed condition is generally the case with almost all of the downtown streets. The disturbed condition continued up Alama Plaza to well beyond the Crockett Street intersection, where the disturbed condition suddenly terminated. This area was where an important portion of the defenses of the Alamo during the 1836 battle was expected to be found.

During September and October 1835, General Cós converted the old mission into a fort for his defense of San Antonio. One of the fortifications 


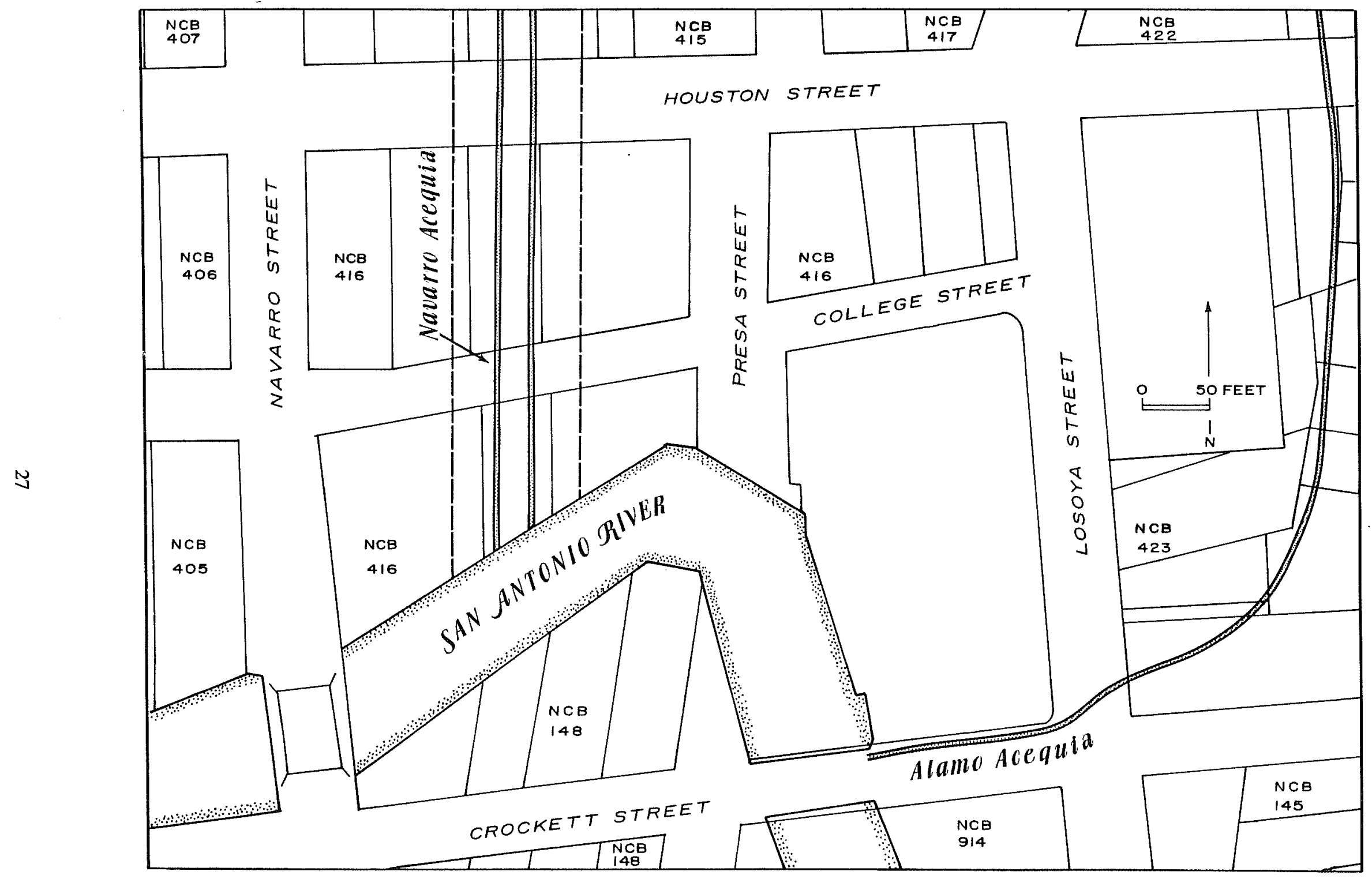

Figure 13. Alamo Acequia at Crockett Street and Navarro Acequia. 


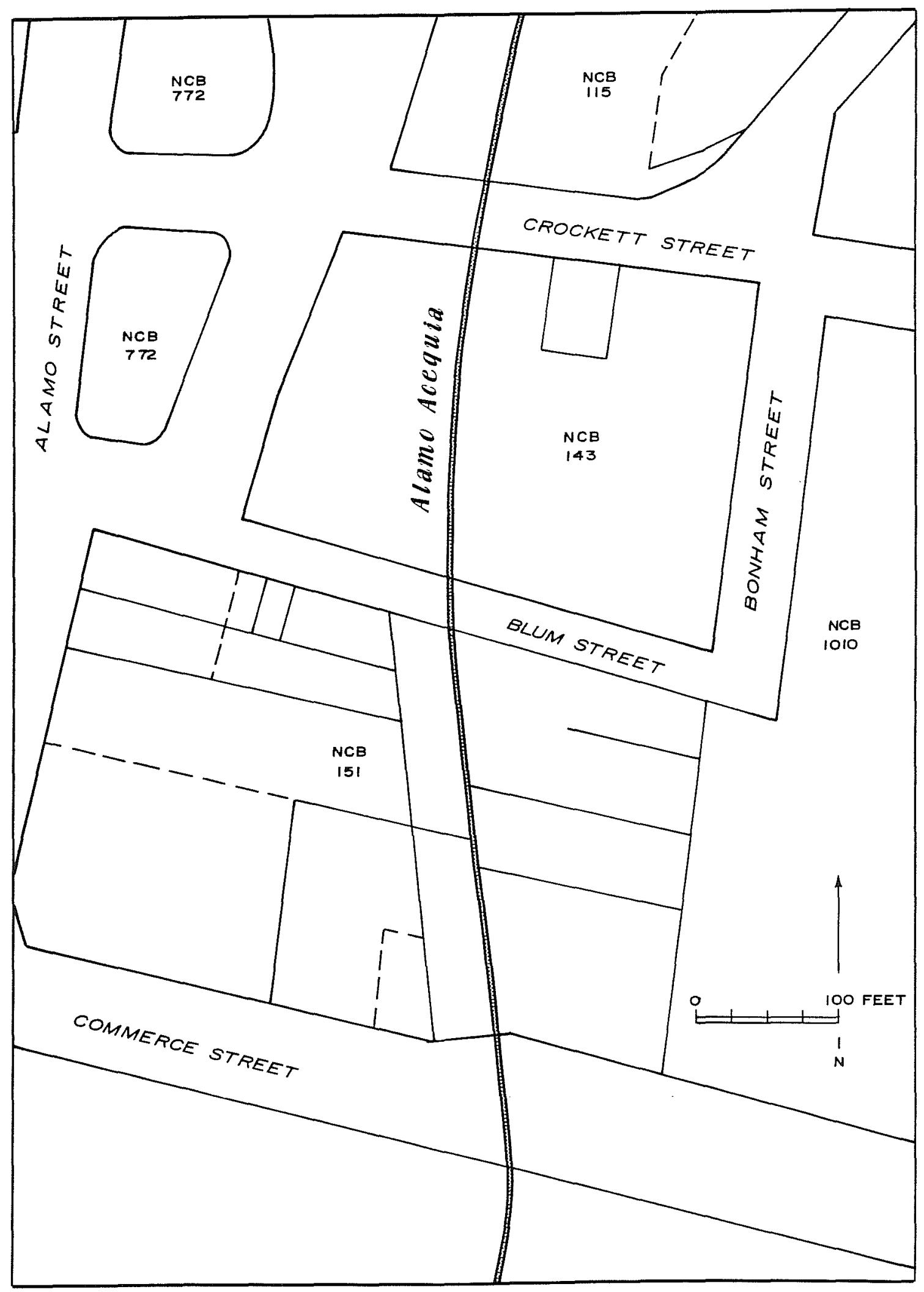

Figure 14. Alamo Acequia at the Alamo. 


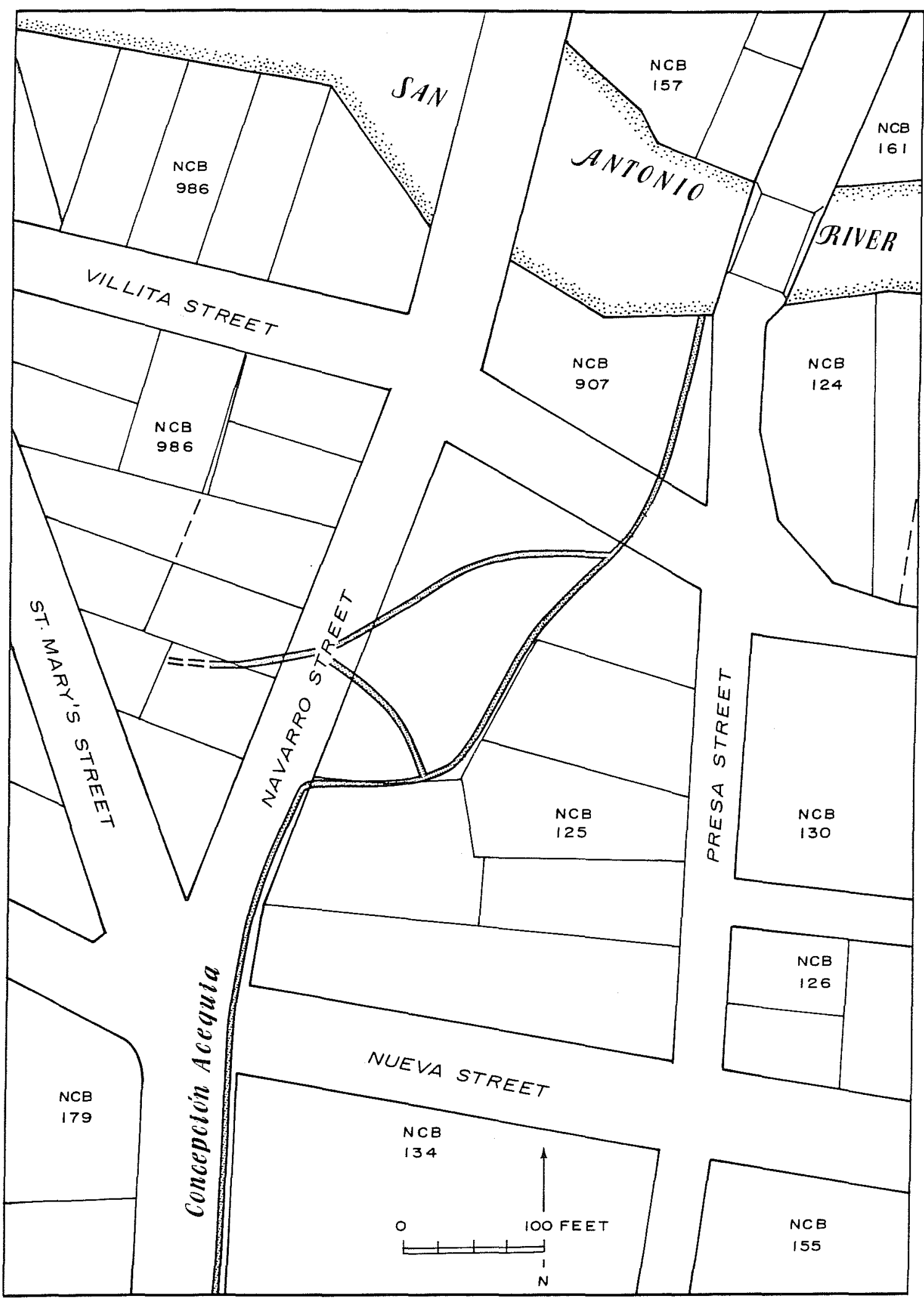

Figure 15. Concepción Acequia. 

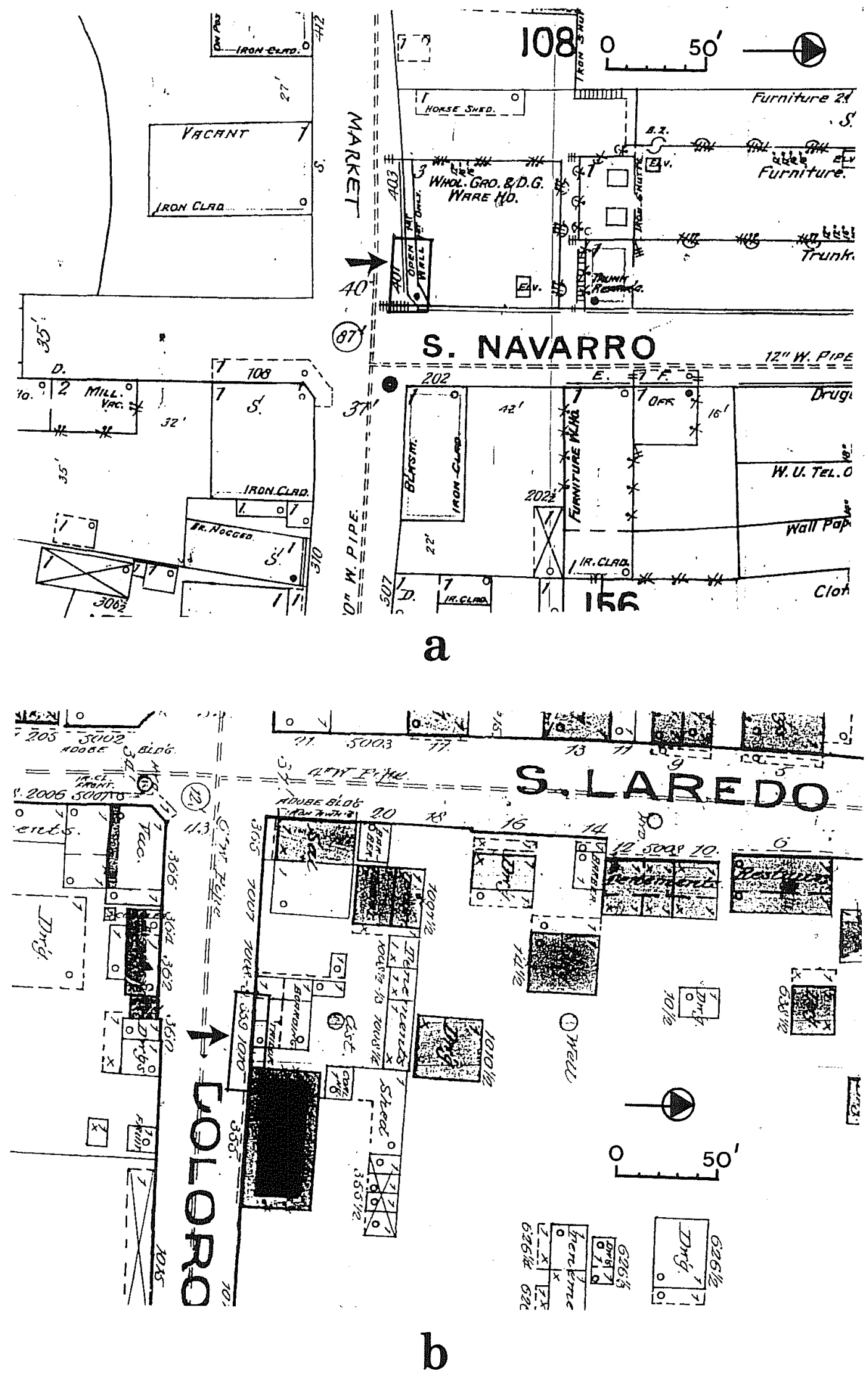

Figure 16. Sanborn 1896 Insurance Maps. Indicated are the original locations of buildings where buried structural remnants were uncovered by Tri-Party street trenching. a, location of the Meyer and Soloman Halff building (41 BX 983); b, location of a boarding house and restaurant structure. 
was a semicircular trench, or lunet, around the south gate of the Alamo. Previously, the summer field school at UTSA had excavated the eastern half of this fortification, and the approaching trench presented an opportunity to examine the western portion as it recurved into Alamo Street. On August 4, the trench was encountered, and artifacts identical to those recovered during the field school were collected. In addition, two walls of the west side of the southern gate, the "low barracks" were also exposed. The information will be incorporated into the field school report (Fox 1992). Immediately north of the barracks, the disturbed condition was again encountered.

The same week, construction crews encountered pier foundations on the north side of Dolorosa Street at the intersection of South Laredo Street (Fig. 16b). The foundations represented two separate structures, one of four wooden posts set on 12-foot centers, and the second structure, toward the west, of brick and concrete piers, also spaced 12 feet apart. The foundations where at 619 and 624 Dolorosa Street. The wooden piers (619 Dolorosa Street) were the remains of a frame boarding house erected prior to 1885 and destroyed by a fire in December 1899 (Sanbom Map and Publishing Company, Ltd. 1885; San Antonio Daily Express 1899:6). The structure was later rebuilt as a restaurant. The brick structure (624 Dolorosa Street) was constructed ca. 1910. All structures at that intersection were destroyed by street alterations in 1928 (Sanborn Map and Publishing Company, Ltd. 1885, 1904, 1911; City of San Antonio n.d.:NCB 254).

On August 23, 1988, the construction supervisor notified the CAR representative that a tunnel had been discovered at the southwest corner of the Federal building on the northern edge of Alamo Plaza. There is a persistent belief in San Antonio that all of the missions are linked by tunnels, vehemently supported by many who insist that they, or their parents or grandparents, have seen them, entered them, or even ridden their horses through them. There is even a romantic tale of a lovers duel and a ghostly specter in which the "secret, subterranean passage that ran from the Alamo to the Mission Concepcion" figures prominently (San Antonio Express 1911:1). Upon arrival, the opening had more the appearance of a solution cavity in the caliche that underlies the plaza, but further excavation revealed that it was unquestionably a dome-shaped tunnel with occasional cedar timber shoring (Fig. 17). A construction worker entered the tunnel and reported that it extended "about one hundred feet" until it had collapsed. The presence of a tunnel in this location appeared rather strange because it would have been within the original compound of the Alamo, and therefore have served little purpose. To fully expose the entrance the excavation was continued, and approximately 12 inches deeper a cast iron sewer pipe, 12 inches in diameter, was encountered, somewhat solving the mystery. Apparently, when the first Federal building was constructed, in 1887, the construction crew who installed the utilities for the building encountered the 18- to 20-inch concrete base for the streetcar line on Houston Street (Fig. 18). Rather than disrupt traffic along the thoroughfare and to avoid the labor of removing the base and rails, the decision was made to tunnel under the street. The "collapsed" portion of the tunnel was, in fact, the backfilled trench on Alamo Plaza, some 60 feet south of the exposed portion of the tunnel.

On December 13, the CAR was informed that building stone had been encountered on St. Mary's Street between Commerce and Market Streets. The foundations in question were in St. Mary's Street and under the sidewalk line of Commerce Street. The portion exposed was cut limestone, ashler dressed with random chisel marks. The remains of the structure once stood at 242-244 West Commerce Street, a two-story commercial building. The building is depicted on the 1885 Sanborn insurance map (Fig. 19a), and remained unaltered through 1904 (Sanborn Map and Publishing Company, Ltd. 1885, 1904), at which time it housed the Rees Optical Company and George Roe, stationary salesman. The building was destroyed when Commerce Street was widened and by the extension of St. Mary's Street to the south of Commerce Street in 1915.

In February 1989, the CAR was alerted by the city historic preservation officer that a structure had been exposed on Main Plaza immediately north of the former location of the Antonio Ruiz home, now relocated behind the Witte Museum. Investigation revealed that the structure was a soft yellow brick utilities servicing entry. An archival search through 1952 failed to reveal any other construction in that location.

Although monitoring continued during the next seven months, no archaeological sites were discovered. This was due to various factors. First, activity was sharply curtailed during the Fiesta period, and the construction work was now concentrating on more shallow excavations, primarily concerned with paving and resurfacing of the streets. As a general rule, any work that did not penetrate below 12 inches did not affect historical resources, and the majority of the work in the streets had already been destroyed by previous utility construction. 


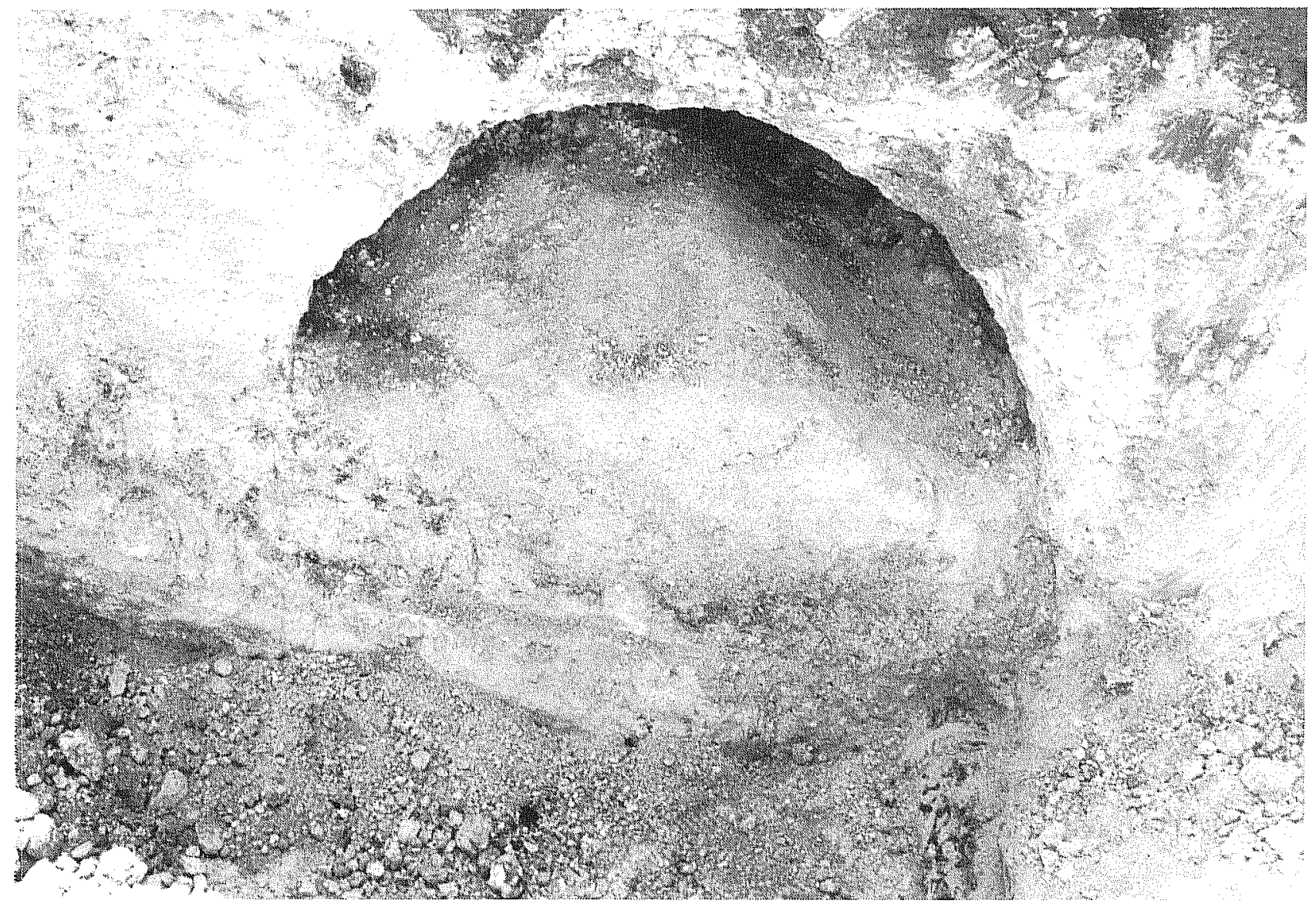

Figure 17. Tunnel on Alamo Plaza. 




Figure 18. Federal Building on Alamo Plaza, 1900-1901. Located on the north side of Alamo Plaza, begun in 1887 and completed in 1890. The streetcar lines can be seen on Houston and Alamo Streets. Courtesy of the Daughters of the Republic Research Library, The Alamo. 

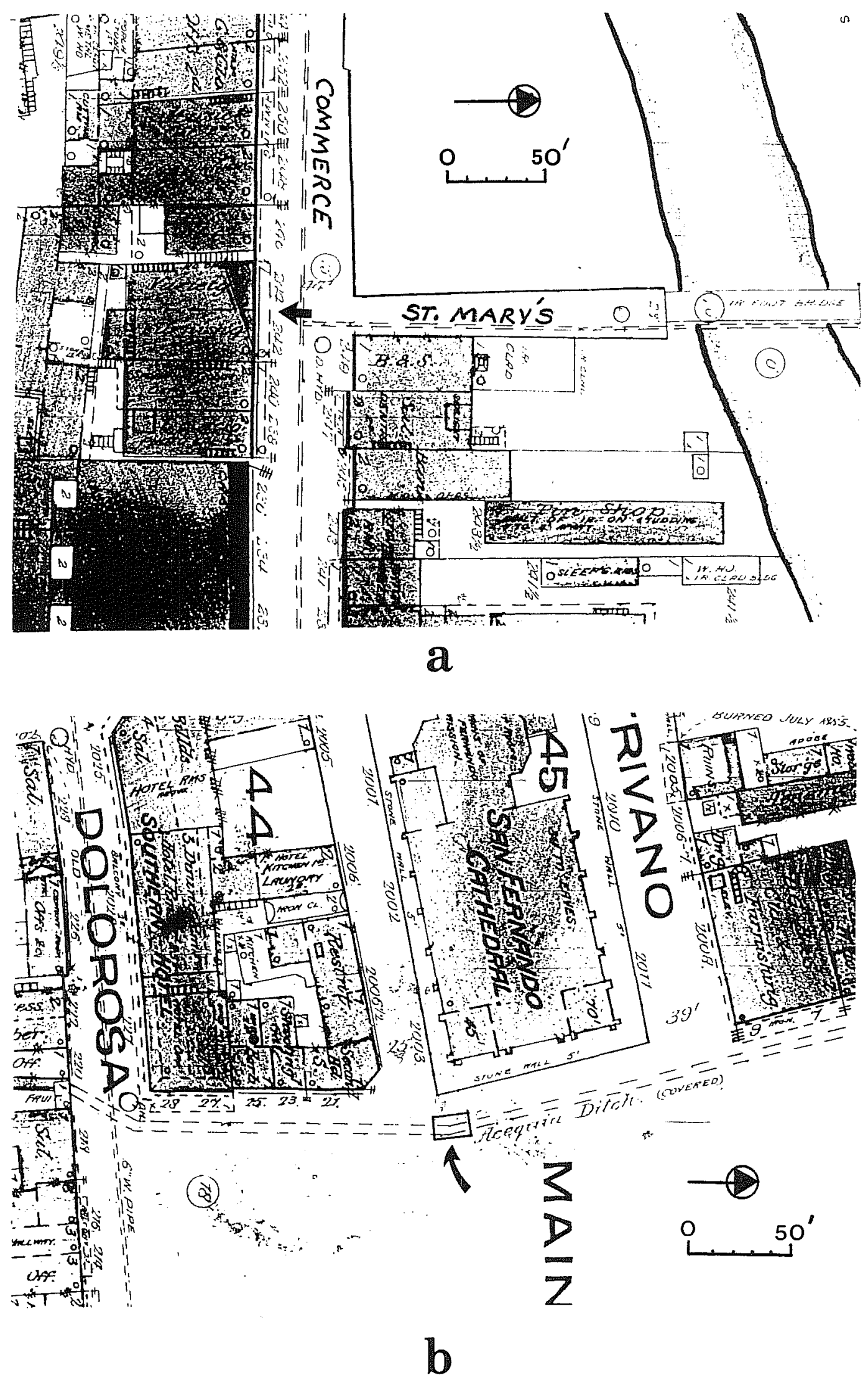

Figure 19. Sanborn 1896 Insurance Maps. Indicated are the original locations of buildings where buried structural remnants were uncovered by Tri-Party street trenching. a, location of the Rees Optical Company building (41 BX 894); b, location of the San Pedro Acequia (41 BX 337) in front of San Fernando Cathedral on Main Plaza. 
In September, a "brick vault" was reported on Dolorosa Street at the northwest corner of South Flores Street. Upon examination, it was found to be a brick-vaulted window arch over a light well into the basement of the Kaufman building. The structure, a two-story brick business building, was constructed ca. 1888 , and previously stood on Lot 1, NCB 100 , facing onto Dolorosa Street. The light well was lined with cut limestone on the exterior with a depth of approximately three feet.

Monitoring continued along Dolorosa Street with special attention directed toward the deep cut in front of the Justice Center as it approached the location of the San Pedro Acequia at the corner of Main Avenue. None of the stone of the acequia was encountered, probably due to the extensive utility construction that had taken place in the area.

Construction, in February 1990, on Commerce Street north of Main Plaza uncovered several wooden ties projecting toward the north from the southern edge of the roadbed. These wooden support ties were for the streetcar line that was added after Commerce Street was widened in 1917. The area was heavily disturbed by pipe lines in all directions.

In April, the San Pedro Acequia was exposed just below the surface of the street by alterations to the bus loading space in front of San Fernando Cathedral (Fig. 20). It was determined that the east wall of the acequia had been fully exposed, but little damage had resulted due to the shallow nature of the alterations. A conference with an architect from the Historic Preservation Board and the rector of the cathedral resulted in a recommendation that the area be resurfaced as soon as possible to protect the acequia for future development. This recommendation was accomplished within the next two days, allowing Fiesta activities to use the area without harm to the acequia. The location of the portion exposed is shown in Figure $19 \mathrm{~b}$.

The following month, June, the CAR was notified that the San Pedro Acequia had again been exposed on the northwest corner of Main Plaza. Examination disclosed that what was exposed was not the original acequia but instead a concrete drainage channel that had replaced the original stone of the acequia. Monitoring continued several days to insure that none of the original stone was in place, but none was found.

Although monitoring continued until completion of the project, no further evidence of archaeological resources were impacted. Again this was due largely because the final work was primarily concentrated upon surface modifications to the streets within the project area.

\section{CONCLUSIONS AND RECOMMENDATIONS}

Considering the magnitude of the project throughout the most critical part of the city, it seems strange at first glance that more archaeological sites were not disturbed. However, a great deal of the area was only affected to a very shallow depth by the installation of brick paving and street resurfacing. The anticipated impact on the various acequias only materialized on one occasion, above the San Pedro Acequia. This was again primarily due to the shallow depth of the alterations and the vast amount of damage already done by the immense amount of utility installation over the past 30 years. The close communication and frequent briefings between the archaeologist, project directors, and construction personnel proved invaluable in anticipating problem areas and minimizing project delays when sites were threatened or exposed. Only minor problems were encountered throughout the construction period, and these were generally after personnel changes had been made and communication had not been fully reestablished. Since all construction has been completed, no further monitoring is required, however, any future work in the area should take into consideration the potential areas noted in this report in planning for further modifications in the downtown area.

\section{REFERENCES CITED}

Almazán, J. A. P. de

1731 Translation of Order for and Report of the Survey of Original Town Tract of San Fernando de Bexar. Copy in the Bexár Archives, Archivo General Nacional de Mexico, Box 20246, No. 822, Barker Texas History Center, The University of Texas at Austin.

Appler, J. A.

1897 General Directory of the City of San Antonio, 1897-1898. San Antonio.

1899 General Directory of the City of San Antonio, 1899-1900. San Antonio.

1905 General Directory of the City of San Antonio, 1905-1906. San Antonio. 


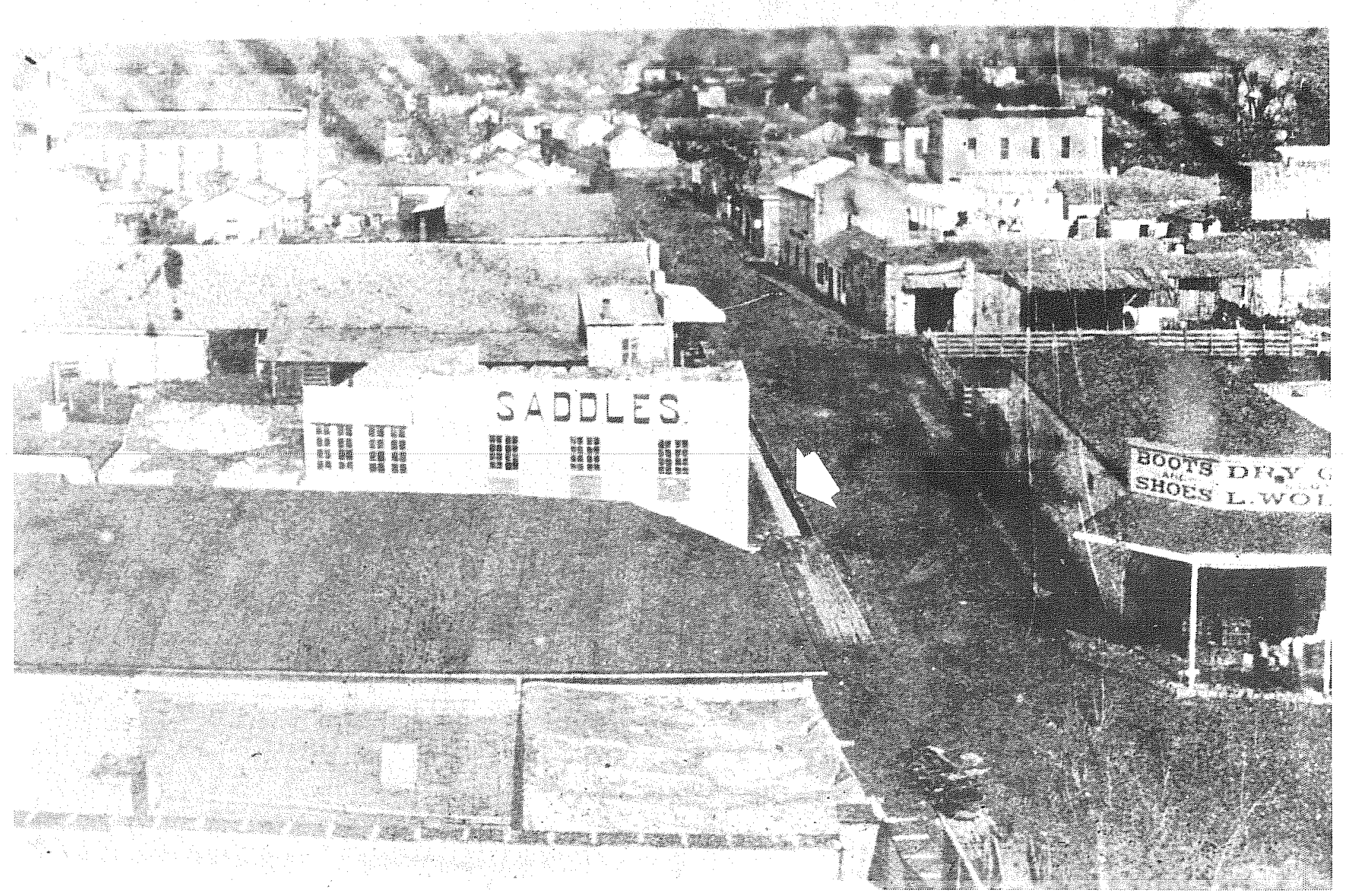

Figure 20. San Pedro Acequia on Main Plaza, ca. 1880. Looking north on Main Avenue from atop San Fernando Cathedral. Note the stone-lined San Pedro Acequia on the west side of the street partially covered with planks. Courtesy of the Daughters of the Republic Research Library, The Alamo. 
Aviles, A. de

1732 Carpeta de Correspondencia de las Provincias Internas por los años de 1726 a 1731. Archivo General Nacional de Mexico. Volume 236:28. Richard C. Garay private collection, San Antonio, Texas.

Bexar County, Texas

Deed Records (DR)

Originals and microfilm in the Bexar County Courthouse, San Antonio, Texas.

Brune, G.

1981 Springs of Texas. Volume I. Branch-Smith, Inc., Fort Worth, Texas.

Burkholder, M. V.

1973 The King William Area. The King William Association, San Antonio, Texas.

Bybee, L. L.

1980 The Germans in San Antonio, 1844-1920, A Study in Cultural Persistence. Masters thesis, The University of Texas at San Antonio.

Castañeda, C. E.

1925 Statistical Report on Texas by Juan N. Almonte, 1835. The Southwestern Historical Quarterly XXVIII(3):177-222, Austin, Texas.

1926 A Trip to Texas in 1828: José María Sanchez. The Southwestern Historical Quarterly XXIX(4):249-288, Austin, Texas.

Chabot, F. C.

1932 Excerpts from the Memorias from the History of the Province of Texas. The Naylor Printing Company, San Antonio, Texas.
1937 With the Makers of San Antonio. Privately published, San Antonio, Texas.

City of San Antonio

1850 City Survey Book. Office of City Engineer, San Antonio, Texas.

n.d. Right of Way Files. Right of Way Office, Main Plaza Building, San Antonio, Texas.

Corner, W.

1890 San Antonio de Bexar: $A$ Guide and History. Bainbridge and Corner, San Antonio, Texas.

Corps of Engineers

1972 Flood Plain Information, Olmos Creek, San Antonio, Texas. U.S. Army, Fort Worth District. February.

Coues, E.

1965 The Expeditions of Zebulon Montgomery Pike, To Headwaters of the Mississippi River, Through Louisiana Territory and in New Spain, During the Years 1805-6-7. Two volumes. Ross and Haines, Inc., Minneapolis, Minnesota.

Cox, I. J.

1902 The Early Settlers of San Fernando. Texas Historical Association Quarterly V:142-161, Austin, Texas.

Cox, I. W.

1985 10th Street Substation Excavation of the Acequia Madre (41 BX 8), San Antonio, Bexar County, Texas. Center for Archaeological Research, The University of Texas at San Antonio, Archaeological Survey Report 153.

1986 Excavation of Portions of the San Pedro Acequia (41 BX 337) and a Search for the Arocha Acequia, San Antonio, Texas. Center for Archaeological Research, The University of Texas at San 
Antonio, Archaeological Survey Report 161.

Daughters of the Republic of Texas Research Library (DRT)

n.d. Alamo Cannon. San Antonio vertical file. The Alamo, San Antonio, Texas.

Delaney, R. W.

1955 Matamoros, Port for Texas During the Civil War. The Southwestern Historical Quarterly LVIII:473-487, Austin, Texas.

Deutschmann, S.

1915 Report of the Widening of Commerce Street. Passing Show Printing Company, San Antonio, Texas.

Environmental Protection Agency

1978 Draft Environmental Impact Statement for San Antonio, Texas, Wastewater Treatment System. EPA Grant No. C-48-1211-01, Region VI, Dallas, Texas.

Everett, D. E.

1975 San Antonio, The Flavor of its Past, 1845-1898. Trinity University Press, San Antonio, Texas.

Faulk, O. B.

1964 The Last Years of Spanish Texas, 1778-1821. Mouton and Company, London.

Fehrenbach, T. R.

1968 Lone Star, $A$ History of Texas and the Texans. The Macmillan Publishing Company, Inc., New York.

1978 The San Antonio Story. Continental Heritage, Inc., Tulsa, Oklahoma.

Fox, A. A.

1992 Archaeological Investigations in Alamo Plaza, 1988 and 1989. Center for Archaeological Research, The University of Texas at San Antonio, Archaeological Survey Report 205.

Garrett, J. K.

1968 Green Flag Over Texas, A Story of the Last Years of Spain in Texas. Pemberton Press, Austin, Texas.

Gilbert, Rev. M. J. (compiler and editor)

1949 Archdiocese of San Antonio, Diamond Jubilee, 1874-1949. Schneider Printing Company, San Antonio, Texas.

Green, R. M. (editor)

1921 Memoirs of Mary A. Maverick. Alamo Printing Company, San Antonio, Texas.

Habig, M. A.

1968a The Alamo Chain of Missions. A History of San Antonio's Five Old Missions. Francisco Herald Press. Chicago, Illinois.

1968b San Antonio's Mission San José. The Naylor Printing Company, San Antonio, Texas.

Hatcher, M. A.

1932 The Expedition of Don Domingo Teran de los Rios into Texas. Preliminary Studies of the Texas Catholic Historiacal Society, Vol 2, No. 1.

Hatcher, M. A. (translator)

1919 Texas in 1820, by Juan Antonio Padilla. The Southwestern Historical Quarterly 23:47-68, Austin, Texas.

Herff, F. P.

1973 The Doctors Herff: A Three-Generation Memoir. Trinity University Press, San Antonio, Texas.

Hoffman, F. L. (translator)

1935 Diary of the Alarcón Expedition into Texas, 1718-1719. Quivira Society 
Publications 5. Reprinted by Arno Press, New York.

1938 The Mezquía Diary of the Alarcón Expedition into Texas, 1718. The Southwestern Historical Quarterly XVI:312-323, Austin, Texas.

James, V. L.

1938 Frontier and Pioneer Recollections of Early Days in San Antonio and West Texas. Artes Graficas Press, San Antonio, Texas.

John, E. A. H.

1975 Storms Brewed in Other Men's Worlds: The Confrontation of Indians, Spanish, and French in the Southwest, 1540-1795. Texas A\&M Press, College Station, Texas.

Johnson, F. W. and Barker, E. C.

1914 Texas and the Texans. Five Volumes. American Historical Press, Chicago and New York.

Kerby, R. L.

1972 Kirby Smith's Confederacy: The Trans-Mississippi South, 1863-1865. Columbia University Press, New York.

Land and Thompson

1885 Historical and Descriptive Review of the Industries of San Antonio, 1885. Reprinted by Norman Brock in 1977, San Antonio, Texas.

Maverick, S. A.

1838 Letter to Mary Maverick, February 26. Maverick Collection, Book A 10 , Barker Texas History Center, The University of Texas at Austin.

Mayer, A. J.

1976 San Antonio, Frontier Entrepot. Ph.D. dissertation, The University of Texas at Austin.
McLean, B. J.

1924 The Romance of San Antonio's Water Supply and Distribution System. San Antonio Printing Company, San Antonio, Texas.

Moody and Morrison

1879 General Directory of the City of San Antonio. Marshall, Texas.

Morgan, B. W.

1961 George W. Brackenridge and His Control of San Antonio's Water Supply, 1869-1905. Masters thesis, Trinity University, San Antonio, Texas.

Morrison, A.

1891 The City of San Antonio, Texas. George W. Engelhardt Publishers, St. Louis. Reprinted in 1977 by Norman Brock, San Antonio, Texas.

Morrison and Fourmy

1881 General Directory of the City of San Antonio, 1881-1882. Austin, Texas.

Nance, J. M.

1963 After San Jacinto, The Texas-Mexican Frontier, 1836-1841. University of Texas Press, Austin.

Nixon, P. I.

1936 A Century of Medicine in San Antonio. Privately published, San Antonio, Texas.

Odom, M. and G. F. Young

1985 The Businesses that Built San Antonio. Privately published, San Antonio, Texas.

Pitts, J. B. III

1966 Speculation in Headright Land Grants in San Antonio from 1837 to 1842. Masters thesis, Trinity University, San Antonio, Texas. 
Quirarte, J.

1983 Letters from Governor Antonio Martinez to the Viceroy Juan Ruiz de Apodaca. Research Center for the Arts and Humanities, The University of Texas at San Antonio.

Ramsdell, C.

1976 San Antonio, A Historical and Pictorial Guide. Revised edition, University of Texas Press, Austin.

San Antonio Daily Express

1877 The Grand Celebration. February 20.

1899 Eight Houses were Ablaze. December 10.

\section{San Antonio Express}

1911 The Strange Duel: A Legend of the Mission Concepcion. April 30.

1927 Historic Bowen's Island, Once Garden Spot now Site for $\$ 5,000,000$ Worth of New Buildings. January 23.

1939 J. H. French, One of San Antonio's Best Mayors. February 28.

San Antonio Express-News

1986 Texas Under Six Flags: Legends and Lore, A Special Sesquicentennial Production, Part IV.

San Antonio Light

1936 Progress Brushes Aside an Old San Antonio Landmark. December 19.

Sanborn Map and Publishing Company, Ltd.

1885 San Antonio, Texas. New York.

1904 San Antonio, Texas. New York.

1911 San Antonio, Texas. New York.
Santos, R. G. (translator)

1981 Aguayo Expedition into Texas, An Annotated Translation of the Five Versions of the Diary Kept by Br. Juan Antonio de la Peña. Jenkins Publishing Company, Austin, Texas.

Schuchard, E. (compiler)

1951 100th Anniversary Pioneer Flour Mills, San Antonio, Texas, 1851-1951. The Naylor Publishing Company, San Antonio, Texas.

Schwarz, T.

1985 Forgotten Battlefield of the First Texas Revolution: The Battle of Medina, August 18, 1813. R. H. Thonoff, editor and annotator. Eakin Press, Austin, Texas.

Sibley, M. M.

1973 George W. Brackenridge, Maverick Philanthropist. University of Texas Press, Austin.

Southwest Research Institute

1979 Environmental Resource Evaluation of Unit 7 of San Pedro Creek and 8-3 Units of the San Antonio Channel Improvement Project. Department of Environmental and Research Engineering, San Antonio, Texas.

Steele, C.

1985 A Journey Through Texas in 1767. $E l$ Campanario 16(1). Old Missions and Forts Restoration Association.

Steely, J. W.

1984 A Catalog of Texas Properties in the National Register of Historic Places. Texas Historical Commission, Austin, Texas.

Steen, R. W.

1948 The Texas Story. The Steck Company, Austin, Texas. 
Steinfeldt, C.

1978 San Antonio Was: Seen Through a Magic Lantern. Views from the Slide Collection of Albert Steves, Sr. San Antonio Museum Association, San Antonio, Texas.

Sweet, A. E. and J. A. Knox

1905 On a Mexican Mustang Through Texas from the Gulf to the Rio Grande. Chatto and Windus, London.

Tous, G. (translator)

1930a The Espinosa-Olivares-Aguirre Expedition of 1709. Preliminary Studies of the Texas Catholic Historical Society I(III).

1930b Ramón Expedition: Espinosa's Diary of 1716. Preliminary Studies of the Texas Catholic Historical Society I(IV).

Turanza, J. P. (editor)

1961 Documentos para la Historia Eclesiastica y Civil de la Provinca de Texas o Nuevas Philipinas, 1720-1779. Colecion Chimalistac de Libros y Documentos Acerca la Nueva España, Madrid, Spain.

United States Department of the Interior, Office of the Census (USDI-OC)

1850 The Seventh Population Census, 1850. Bexar County, Texas.

1860 The Eighth Population Census, 1860. Bexar County, Texas.

1880 The Tenth Population Census, 1880. Bexar County, Texas.

1890 The Eleventh Population Census, 1890. Bexar County, Texas.

1900 The Twelfth Population Census, 1900. Bexar County, Texas.
Urrutia, J. de

1767 San Antonio, Texas, in 1767. Department of Manuscripts, The British Library, London, England.

Webb, W. P. (editor)

1952 The Handbook of Texas. Two volumes. The Texas State Historical Association, Austin, Texas.

White, G.

19831830 Citizens of Texas. Eakin Press, Austin.

Wynes, C. E.

1962 Lewis Harvie Blair: Texas Travels, 1851-1855. The Southwestern Historical Quarterly LXVI:262-270, Austin, Texas. 
